"Leveraged buyout booms and busts: can Islamic finance help prevent and mitigate such market distortions?"

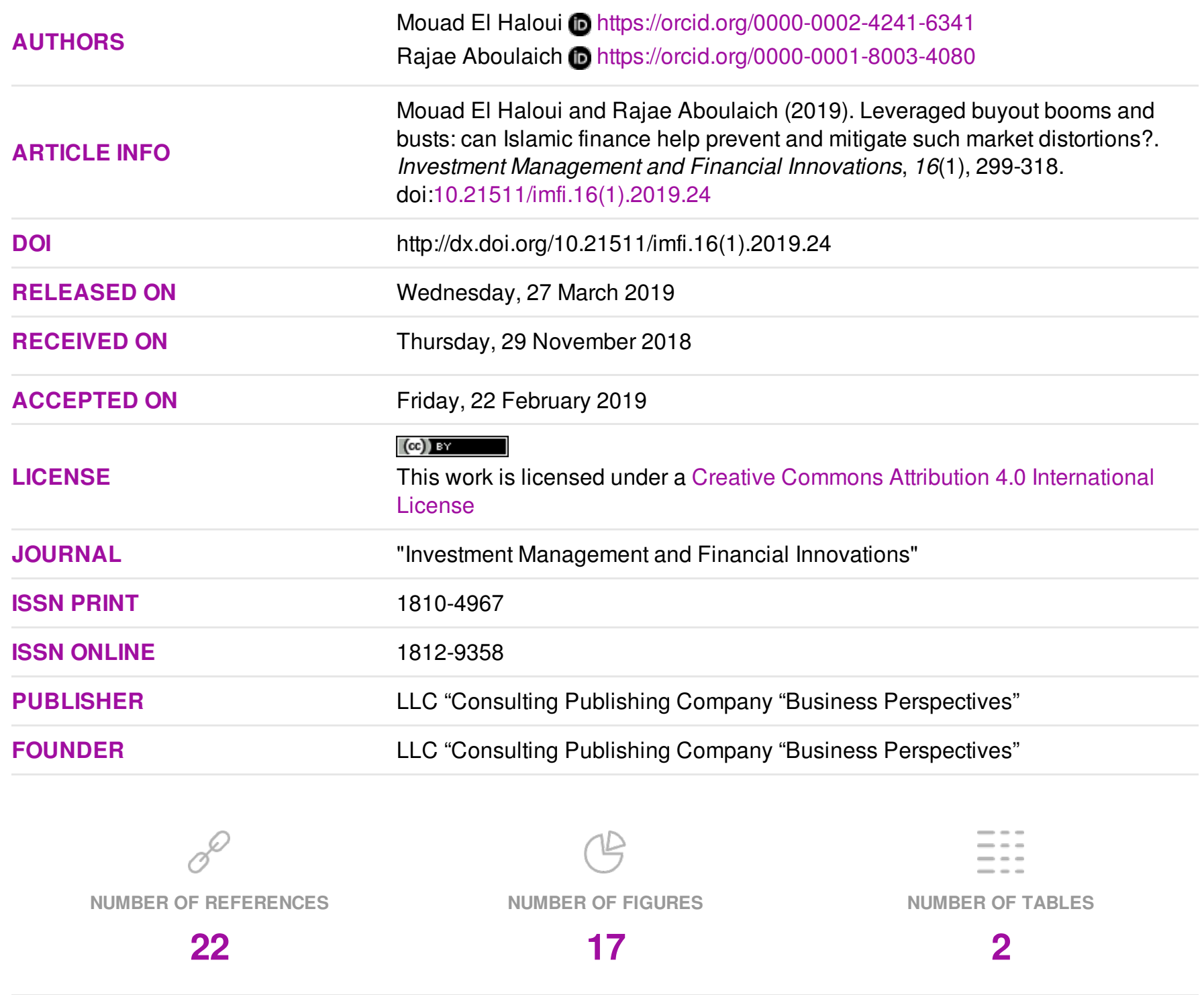

(C) The author(s) 2022. This publication is an open access article. 


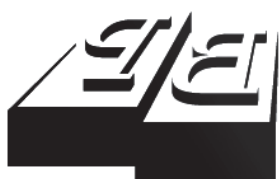

BUSINESS PERSPECTIVES

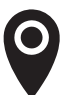

LLC "CPC "Business Perspectives" Hryhorii Skovoroda lane, 10, Sumy, 40022, Ukraine

www.businessperspectives.org

Received on: $29^{\text {th }}$ of November, 2018 Accepted on: 22nd of February, 2019

(c) Mouad El Haloui,

Rajae Aboulaich, 2019

Mouad El Haloui, Ph.D. Student, Department of Financial Engineering, Mohammadia School of Engineering, Mohammed V University of Rabat, Morocco.

Rajae Aboulaich, Professor of Applied Mathematics, Department of Applied Mathematics, Mohammadia School of Engineering, Mohammed V University of Rabat, Morocco.

\section{(ㄷ) (i)}

This is an Open Access article, distributed under the terms of the Creative Commons Attribution 4.0 International license, which permits unrestricted re-use, distribution, and reproduction in any medium, provided the original work is properly cited.

\title{
LEVERAGED BUYOUT BOOMS AND BUSTS: CAN ISLAMIC FINANCE HELP PREVENT AND MITIGATE SUCH MARKET DISTORTIONS?
}

\begin{abstract}
The industry of private equity and leveraged buyout has been, since its beginnings, subject to several chapters of bubbles and busts, the majority of whom are initiated under similar circumstances (excess of liquidity, junk debt and mimetic behavior).

The Islamic finance is a financial system that complies with the rules of the Sharia Law, and which naturally allows the achievements of purposes of Sharia, such as protection of property and capital, fair wealth distribution, reduction of uncertainty and speculation, to name a few.

From this perspective, this paper discusses the capacity of Islamic finance to help prevent some factors that trigger financial crises in the leveraged buyout market and to accomplish the intended purposes through this asset class.

In the first part of this paper, the authors try to break down some of these common factors that trigger or catalyze the economic booms of the leverage buyout industry, and propose a framework to visualize their effects through an agent-based Simulation program. The second part of the paper describes how Islamic economic principles constitute brakes to some distortions and excesses in the market, in such a way that the probability of occurrence of a boom decreases drastically. Finally, these Islamic features are added up to the simulation to provide a comprehensive benchmark.
\end{abstract}

\section{Keywords}

\section{JEL Classification G010, G400, G100}

\section{INTRODUCTION}

The private equity has been, for decades, a misunderstood asset class. Today, thanks to several factors, it has an aura that exceeded that of major asset classes, especially the leverage buyout (LBO), which accounts for more than $40 \%$ of the private equity raised funds (Preqin, 2017). In fact, in the most important markets, monetary policy is favorable, economic growth is accelerating, most economic indicators are moving in the right indicators, and credit is plentiful and relatively cheap.

However, although it is a flourishing market which is gaining more and more confidence, many economists claim that it is time to be prudent to avoid a high exposure to the private equity asset, as the risks of being caught in an under-performing vintage have been growing for the past few years. Indeed, the performance of the LBO exhibits very high volatility depending on the fund vintage, and the market was subject to many ups and downs during the last decades, especially due to the high financial leverage of underlying companies (Lustenberger, 2007). 
On the other hand, since the emergence of Islamic finance in the modern era, at the beginning of the 20th century, many economists suspected the sustainability of such a model, often mentioning complexity, expensiveness or even worse describing it as a "fragile" way of bypassing Sharia precepts.

This hasty appraisal will vanish very rapidly, as economic disasters affected the vast majority of world financial places, pushing investors to look for alternative economic models. This had led many economists to have a deep understanding of the Islamic finance and assimilate its underlying purposes: protecting property and capital, reducing economic disparity and avoiding economic booms and busts, to name a few.

This popularity has been proven in the reality, as Islamic finance exhibited high financial performance year after year: a good illustration is the value of sovereign sukuk, issued outside the Middle East and Southeast Asia by non-Muslim countries that exceeded \$2 billion in 2017 vs. $\$ 1$ billion recorded in 2015 according to Dealogic data, but also a high resilience in times of market turbulence, especially for the main asset classes, as it is the case of Sharia compliant equities (Alam, 2010).

In the existent literature, many are searchers tried to combine the private equity asset class with the Islamic finance principles in order to demonstrate how this type of alternative financing can enhance the performance-risk-liquidity profile and, more importantly, help the private equity market cope with market downturns (Ahmed, 2010).

We try, through this work, to bring a new brick to this wall of arguments by focusing on one important aspect of the private equity asset class, which is the leverage.

In fact, the paper focuses on the effect of the leverage in creating booms and busts in an auction-driven LBO market. The market consists of a set of private equity funds, which acquire target companies through LBO operations, preceded by auction processes where the high bidder takes the deal.

We examine two different market configurations.

The first configuration concerns a conventional market, where target companies can be as leveraged as possible, and debt is indefinitely available and blatantly misused, regardless of its quality (banks, hedge funds, ...). Investment decisions are based on company performance, but also on the behavior of some "driver" funds, which have a strong prominence on the market, thus influencing peer decisions.

The high availability of debt and the possibility to reach high leverage levels leads to a high competition and an exorbitant rise in the market prices, followed by a chain of bankruptcies due to the leverage burden.

The second configuration describes a Sharia compliant market, where target companies cannot exceed a certain threshold of leverage (e.g. 33\%) and the imitation effect is less apparent, as no fund has enough track record to influence the market.

The simple "safeguards" imposed by the Islamic Law are enough to prevent unfounded price rises and bankruptcies, and lead to a market equilibrium.

This paper sheds light on some interesting topics in the private equity industry such as leveraged Buyout market features in the conventional market (Fraser-Sampson, 2011; Kaplan \& Stromberg, 2009) and under Sharia Law (Farid, 2012), dynamics of bubbles in the LBO market (Acharya, Franks, \& Servaes, 2007), auction processes features in the conventional market (Lowenstein, 1985; Ang, Hutton, \& Majadillas, 2014) and under Sharia Law (Olayemi et al., 2015), impact of imitation and influence on market dis- 
tortions [fallacies of decomposition] (Meyer, 2014; Al-Suwailem, 2008) and complex systems and the imbalance between exogenous and endogenous variables [Complexity vs. Chaos] (Al-Suwailem, 2008).

The aim of this paper is to point out the contribution of Islamic finance in preventing some of the LBO market distortions, in particular, bubbles and crashes.

\section{DEFINITIONS}

In this section, we define some concepts that will help to understand the buyout market and the features used in the modelling sections.

\subsection{Leveraged buyout}

As defined by Kaplan and Stromberg (2009) and Fraser-Sampson (2011), leveraged buyout (LBO) is a type of private equity strategy that can be illustrated as the purchase of a controlling stake in a private company or a publicly listed company going private, usually financed with a small portion of equity and a relatively large portion of outside debt. Unlike other private equity strategies such as venture capital, which targets emerging or young companies, LBO funds usually holds majority interests in mature firms with low market risk and high cash-flow generation so that they can meet the high leverage level specific to this type of acquisition. A typical LBO transaction can be illustrated by the following chart.

It is to bear in mind that this illustration is very simplistic. In fact, many factors may alter the presented structure, such as initial debt in the tar- get company, presence of many tranches of credit (mezzanine, second lien, senior debt), co-investment of several funds with different types of shares, etc. Nevertheless, all in all, this is a good description of the main components of an LBO deal.

\subsection{Enterprise value, EBITDA and EBITDA multiple}

In their famous book "Corporate Finance", Vernimmen and Quiry (2014) define the below mentioned concepts that help measure the economic value and performance of companies. The Enterprise value of a company is the amount of money for which it is actually sold and which, after repayment of outstanding debt, will belong to the shareholders:

Enterprise value $=$ Equity value + Debt or

Enterprise value $=$ Market capitalization + Market value of debt - Cash equivalents

There are other ways to calculate the Enterprise value of a company. Besides the net asset value, which

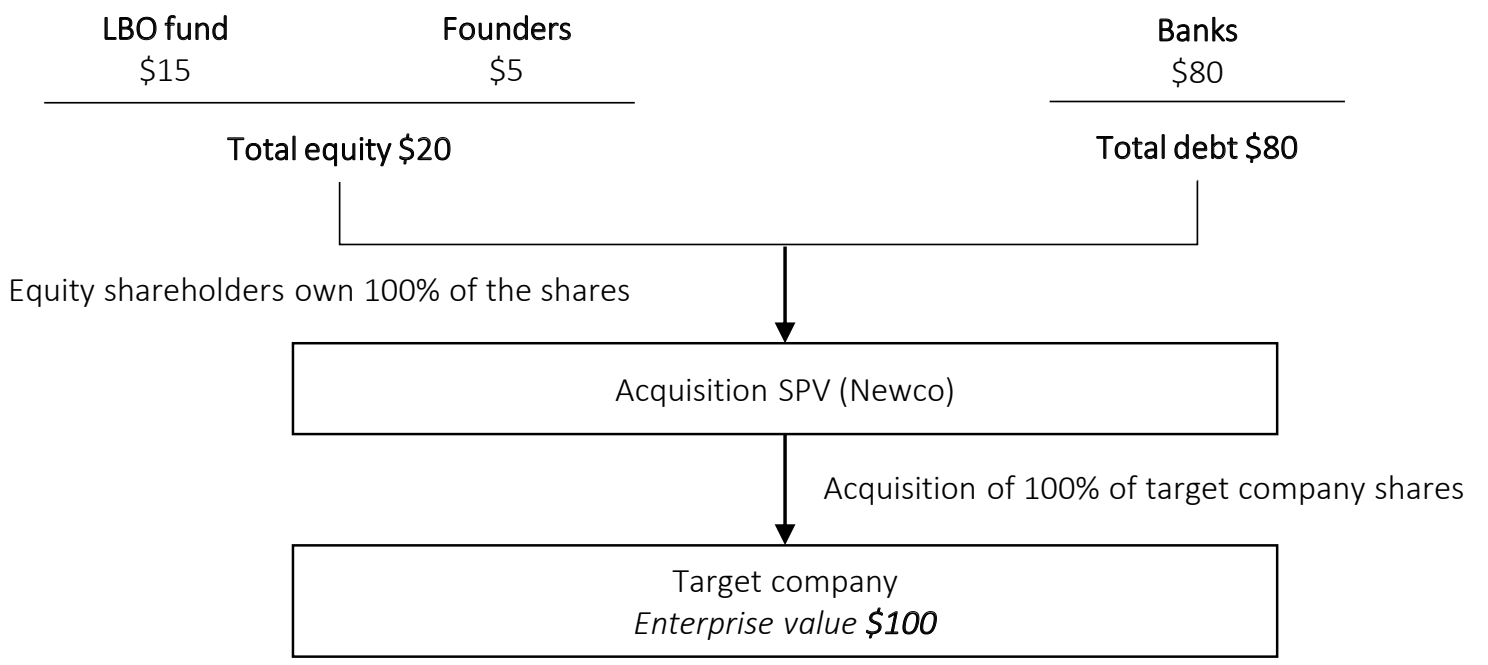

Figure 1. A simple illustration of an LBO deal structure 
derived directly from the definition, there are two primary methods the value a company: the discounted cash-flow or DCF method, which assumes that the value of a company is the present value of all monetary benefits, or the comparable method, which assumes that some economic ratios, such as price-to-earning ratio $(\mathrm{P} / \mathrm{E})$, or EV/EBIDTA ratio, are similar for comparable companies that share the same characteristics (size, industry, geography, etc.) (Vernimmen \& Quiry, 2014).

This is the approach we used to value companies in this paper, using enterprise value-to-Ebitda (EV/ EBITDA).

EBITDA (earnings before interests, taxes, depreciation and amortization) is an indicator of the economic performance of the company. It is claimed to be a pure cash flow measure, since it excludes non-cash flow items such as depreciation, and comes before debt service and taxes. In other words, it eliminates the effect of accounting methods, financial structure and government tax policies. EBITDA was introduced as a common economic indicator by buyout companies in the late 1980s to help measure the ability, or otherwise of a company to service certain levels of debt.

EBITDA multiple is defined as the quantity $m$, which shall be multiplied by the EBITDA to obtain the company valuation:

$$
\text { Enterprise value }=m \cdot \text { EBITDA } .
$$

As mentioned earlier, EBITDA multiple is a powerful tool to compare the expensiveness of a market, a specific sector of a company. In general, depending on several factors (economic conjuncture, availability of cash/debt, sector, ...), the market converges to a market multiple, where the called implicitly agrees on a certain level of a multiple to be the standard. Nonetheless, in periods of booms where cash and debt are abundant and "real" opportunities are scarce, many transactions are concluded with premiums over the market multiple, or also in other distressed situations (for example, for a fund that cannot find buyers for participation, huge discounts may apply).

Reminder: There are other ways to calculate the enterprise value of a company, why only EBITDA multiplier?? Should be explained in summary or the other means should be inserted as a summary.

In the next section, we try to emphasize some of the most important factors that are behind the formation of booms in the LBO market.

\section{METHODS}

In this section, we will explain the methods used to understand some potential distortions of the leveraged buyout market, namely bubbles and crashes, and introduce the scientific procedure used to replicate such a phenomenon and model the behavior of market agents.

\subsection{Understanding the contributory factors of LBO market bubbles}

The factors that are behind this market distortion are ubiquitous in almost all the historical bubbles of the LBO market; they have been always spotted as the main reasons of this behavior, or at best very strong catalysts that cause financial crises to worsen.

\subsubsection{Flood of cash}

With investors everywhere on the hunt for yield, private equity becomes a favored alternative asset for institutional investors who have the patience for longer-held bets. In its 2017 Global Private Equity report, Bain \& Company states that this specific configuration creates a flow of cash towards the private equity funds, which start raising more money that they can spend (Bain, 2017). However, the belief of finding a hidden "gem" is nothing but a big illusion: despite the increase of popularity of the private equity industry as a high performing asset class, the presence of a huge sampling bias cannot be denied. Several research projects, including the work of Phalippou and Gottschalg (2008), have indeed reported that the bulk of fund data sets used for aggregate performance and in the practice do not include all of the low-performing funds. And that is not counting the media effect that highlights very profitable deals and funds, while remaining silent on the bulk of bankruptcies and counter-performances of the industry. All in all, many new investors in- 


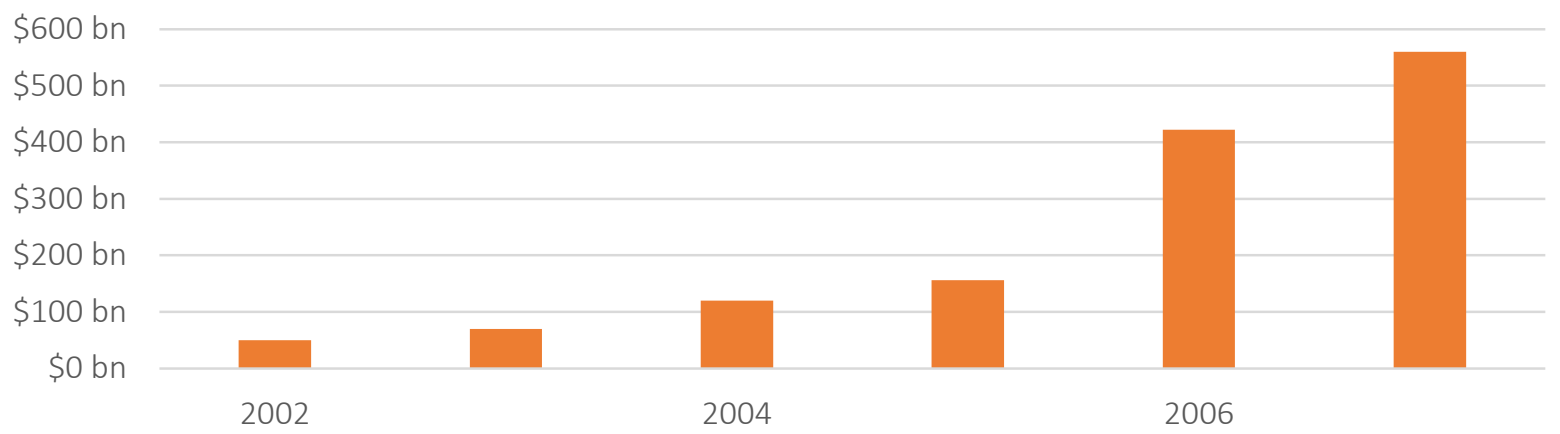

Figure 2. Value of leveraged buyouts in the US in $\$$ billions

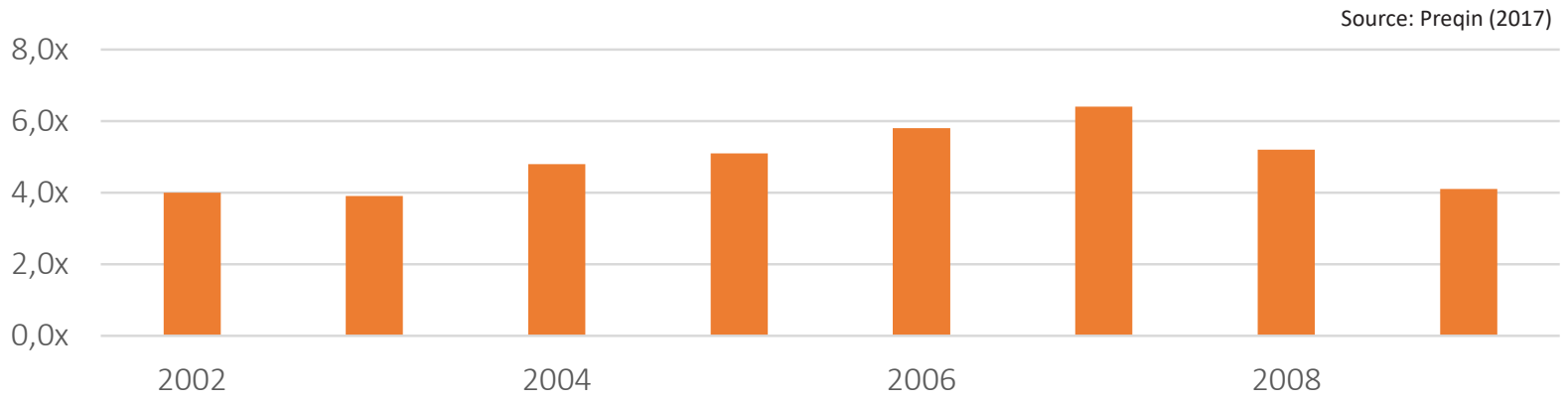

Figure 3. Debt to Ebitda ratios for leveraged buyouts in the US

tegrate the market to catch a piece of the pie without full knowledge of the underlying risk of this asset class.

Cheap debt is the fuel: the second part of the leveraged buyout equation is debt. The flood of cash which triggers the rise of prices is de facto accompanied by a high growth of debt. To complete their transactions, LBO firms borrow either through banks or by issuing junk bonds (in the name of acquired companies) (Chu, 1990).

This high yield debt that the market could offer attracted many risk-insensitive banks and hedge funds that were starving in front of a very low fixed income market, consisting mainly of safe treasury bonds. According to Thomson Financial, in the first half of the 2000 decade, $C$ junk bonds were accounting for more than $25 \%$ of junk bond issued for the US LBO market (Hurduzeu \& Popescu, 2015).

In addition, banks maintain artificially this unstable equilibrium by allowing companies to borrow more to pay interest or to pay down debt, creating a Ponzi scheme in the market, which will burst sooner or later in the hands of the last lender who accepts to bear the risk. In front of this market ecstasy, shareholders of target companies become greedier and do never accept the first bid that comes along, no matter how rich it is. As long as investors can finance their bids, they will pay higher prices.

Figure 2 shows the dramatic increase of leveraged buyout volumes in the US during the 2008 boom, while Figure 3 shows the debt ratios to Ebitda for the same period where levels of debt were close to $7 x$ Ebitda.

\subsubsection{Impact of auctions in catalyzing the process}

Auction is defined in the legal context as 'a method of sale in which parties are invited to make competing offers (bids) to purchase an item in its classified form'. In the LBO market, auction represents an usual acquisition method in which several potential buyers indicate interest and submit several rounds of bids to acquire a target company. Auctions often occur in the secondary buyout sales, where companies already backed by a private equity firm are made for sale by the fund managers.

In a typical auction process, the LBO firm either approaches or is approached by potential strategic and financial acquirers to start a sale negotiation. As a standard auction, potential acquirers submit 
bids with higher prices at each round. Generally, the winner is the highest-price bidder, but sometimes the LBO fund can make strategic sales at lower prices, if any interest remains in the sold company.

Auctions are a usual method of selling the companies in the LBO market. However, unlike negotiated sales, this method becomes preponderant in boom periods. Lowenstein (1985) reports that the reason is that price premiums generated with competing bidders are significantly larger than the premiums in deals with no competing bids, and the propensity of bidders to pay expensive multiples and to aggressively compete for deals is very high in these periods (see also Ang, Hutton, \& Majadillas, 2014).

Auctions reflect an economic behavior where each bidder submits a price, which is a function of his wealth, the expected return, but first and foremost a function of other bids (in this case, maximum of prices plus a premium), as low bids are not considered by the buyer. In boom periods, neither wealth nor return are big issues because of the flood of bank debt, and the high allowed leverages in the first hand, and because the market bullish trend promises high expected IRR (Internal Rate of Return) when reselling the company through another auction process as a secondary or tertiary LBO.

As stated by Al-Suwailem (2008), the system becomes "highly relative", as "higher demand creates higher returns which induces further demand [...] that may transform the market to a Ponzi scheme".

\subsubsection{Impact of imitation}

During the history of the LBO market, returns have exhibited a "very large" dispersion around the median or the mean return. A study conducted by Cochrane (2005), reported a mean volatility of $86 \%$ p.a for a sample of 16,638 private equity transactions, calculated via maximum likelihood estimates and sample bias correction for unobservable returns. The sample exhibited also a high skewness towards negative returns. Nevertheless, according to Preqin (one of the largest databases of the private equity industry), a set of funds, such as KKR and Blackstone, have consistently outperformed the market, and ranked top quartile or top decile of the benchmark (Preqin, 2017).
These firms, generally staffed with great management teams, with a high-quality value creation approach, can have significant influence on the market.

Meyer (2014) states that the basis for generating superior performance in the private equity market is "being able to decide independently from one's peers or even being contrarian", however, lack of knowledge of the best opportunities and difficulty of access to certain potential home-run investments pose an obstacle for many private equity companies. In this respect, who are perceived as market leaders "promote good opportunities, and take a long view of what determines value, can open doors and provide market intelligence, and are imitated by less experienced [firms]".

For novice investors, especially in boom periods, where cash and debt are available even for non-experienced investment teams, an acceptable strategy would be essentially being a follower of investors that are perceived as having high skills. Copying the behavior of respected peers will obviously not result in a market out-performance, nevertheless, it is a good protection against a blatant under-performance.

This can lead to a herd behavior, which is a "fallacy of composition", as mentioned by Al-Suwailem (2008). When the majority of market agents are imitators, and follow mindlessly their peers' decisions, assuming that the latter are relying on "private information", this creates a positive feedback loop and high relativity (Al-Suwailem, 2008).

In the next subsection, we will present the methodology used to model the same LBO market configuration under the Sharia framework and try to bring out how the Islamic Law prevents the market from going in chaos.

\subsection{Islamic finance contribution in the alleviation of LBO market bubbles factors}

\subsubsection{Introduction to Sharia compliant private equity}

In its broader sense (i.e. including other strategies such as venture capital), private equity captures the essence of the spirit of Islamic Law for two main reasons. First, it reflects the shirked type of 
financing, such as musharakah and mudharabah, which adhere to the profit-and-loss sharing principles of Islamic Law (Farid, 2012), and, secondly, because the main targets (sweet spot) of the private equity investors are the SMEs (small and medium enterprises), thus encouraging youth entrepreneurship and creativity. However, in order to "fully" abide by the Shariah Law, the private equity fund should ensure there are no interest charges, or investments involving products and services that are forbidden.

\subsubsection{Industries permissible according to Islamic Law}

To ensure that an Islamic LBO fund is Shariah compliant, one of the most important criteria to watch out is the industry of the underlying companies. In fact, the companies the fund invests in should be permissible in Islam such as healthcare, IT, hospitality, to name a few. Businesses involved in gambling, alcohol, tobacco, pork and adult entertainment are examples of businesses that are not permissible in Islam. This criterion reduces the universe by roughly $10 \%$, according to a study conducted by Biancone and Radwan (2016), on a sample of 2.9 million European companies, which has been reduced to 2.6 million after exclusion of Haram business activities.

Like investments in publicly listed companies, it is generally accepted that any illicit income of a target company should not exceed 5\% (or 15\% according to some other scholars) of overall gross income, so that it is assumed marginal or incidental (Wouters, 2008). In all cases, this illicit income should be cleansed later.

\subsubsection{Impact of the Islamic Law in reducing the boom catalyzers}

Restricted leverage criteria: the Islamic Law bans any company that is "contaminated" by riba-based debt. However, as it is extremely difficult to find companies that are "interest free", most Sharia scholars have recognized and admitted that companies may contain partial debt without being completely unacceptable for investment.

One of the most significant innovations in this field, was the methodology ("fatwa") set out in 1987 by leading Islamic finance scholars Muhammad Taqi Usmani, Prof. Saleh Tug and Sheikh Mohammas Al Tayed Al Najjar concerning equity investment, which allowed Dow Jones to develop the Dow Jones Islamic Index in 1999 (Wouters, 2008).

This index follows criteria established in the 1987 fatwa that allow to extend, to a certain level, the investment scope to companies that have some conventional debt. In fact, the total debt of the company can be tolerated up to $33 \%$ of market capitalization or equity value, the short-term securities should not exceed $33 \%$ of market capitalization or equity value, and finally the accounts receivables should not exceed $33 \%$ of total assets.

In a nutshell, companies will be out of the eligible scope, if they are too exposed to long-term financing debt, short-term securities or suppliers' loans that may create liquidity issues.

Case study "Aston Martin": one of the first and most iconic LBO operations that took place through Shariah compliant means was the Aston Martin acquisition from the car company Ford. The operation was backed by two Kuwaiti financial groups, Investment Dar and Adeem Investment Company. Both invest only in accordance with Islamic principles. Ford has suffered significant losses in the headquarters operations and the sale of Aston Martin was a strategic decision to reduce its accumulating debt. The deal involved $\$ 540$ million, and was financed up to $60 \%$ by equity contributors above and to $40 \%$ through a mudharabah facility provided by West LB. Ford retained a small stake in the company alongside the new acquirers through a murabaha commodity structure, based on a profit and loss sharing mode of financing (Farid, 2012).

Olayemi et al. (2015) state that "the process of auction is similar to the process of 'Bay' al-Muzayadah', which is a recognized contract under Sharia. 'Bay' al-Muzayadah' is defined as the intermediation between seller and buyer, or between lessor and lessee, in order to determine the amount of the price of the commodity or services that is intended to be acquired, or the value of the leased item, based on mutual acceptances of the counter values by the par- 
ties (Muhammad Ali al-Hashmiri et al., 1997). They later outline that Islamic scholars have two opinions on the permissibility of auction 'Bay' al-Muzayadah':

Majority opinion: "The majority of the scholars of the Islamic schools of law argue that 'Bay' al-Muzayadah', auction is permissible under Sharia. Some of the scholars that hold this opinion include Kasani, a jurist of the Hanafi school of law (Al-Kasani, 2003), and Imam Bukhari who specified a topic for it in his book. In another opinion, Bay' al-Muzayadah' was practiced during the time of the holy Prophet, S.A.W. by his companions in the sale of war booties. In addition, the companion of the Holy Prophet Anas Bin Malik reported that the holy Prophet (S.A.W.) once sold a carpet and a water vessel by calling out to people for bid. A man offered to purchase it in one dirham, but the Prophet demanded higher bid. However, when another person offered to purchase it in two Dirham, the Holy Prophet accepted it and sold it to him (Sunnan Al-Tirmidhi, 884 (1996)). Other jurists who hold similar opinion are Ibnu humam (n.d.), a jurist of Hanafi school of law, Ibn Juzaiy (n.d.), a Maliki jurist, and Ibn Qudamah (n.d.) who is a jurist of Hanbafi school of law who insisted that there is al-Ijma' 'consensus of opinion' on the permissibility of al-Muzayadah auction across the various Islamic school of law".

Minority opinion: "However, some scholars opposed to the practice of 'Bay' al-Muzayadah' auction. Their contention emanates from the interpretation of the hadith of the Prophet that prohibits the bargaining of a Muslim over the bidding of another person. The hadith states that: 'A Muslim shall not bargain on the transaction of his brother (fellow human being), (Sahih Muslaim, No. 3088, 1314). They therefore contend that 'Bay' al-Muzayadah' is not permissible based on this hadith. However, this argument is rejected by the majority of scholars. They maintain that the bidding or bargaining on the bid of another person cannot be prohibited except after the acceptance of the offer. They maintain that this is not the case of 'Bay' al-Muzayadah', where there is no acceptance yet. Therefore, the transaction cannot be said to have been concluded except after the auctioneer has accepted the highest bid".
Based on the above arguments, the Malaysian Shariah Advisory Council (SAC) resolved on October 16-17, 1997 to adopt the opinion of the majority of scholars (Olayemi et al., 2015).

\subsubsection{Imitation}

The imitation behavior is also present within the Islamic market with the same intensity. However, as the Islamic private equity market is not deep enough, no fund has a distinguished track record to influence its peers in investment decisions. In our model, the propensity to imitate peers is assumed to be the same, but the number of driver funds in the market is far lower than in conventional one.

In order to emphasize these behaviors, the next subsection will be dedicated to the modelling of an LBO market in both cases; conventional and Sharia compliant. LBO funds and companies interact within a simulated configuration where all the above ingredients are persistent. The results will therefore confirm or deny the initial assumptions.

\subsection{Modelling of a leveraged buyout market: conventional vs. Sharia compliant}

\subsubsection{Description}

We examine a universe of funds investing in target companies through leverage buyout transactions. Bank debt is highly available so that funds can achieve $90 \%-95 \%$ of leverage in the conventional case vs. $33 \%$ in the Sharia compliant case.

A proportion of the funds are considered to be "drivers". This proportion depends on the market case: $10 \%$ for conventional vs. $3 \%$ for Sharia compliant.

Funds invest through a two-time process: first, each fund spots the companies that he is interested in, launches a due diligence and calculates a score weighted between a performance criteria and the behavior of "drivers". This results in a binary go-no-go decision. Second, the fund enters in an auction process against other funds targeting the same companies. At each round of the process, 
each fund either submits a higher price (if permitted by its equity ticket) or leaves (according to a certain probability).

The model implementation joins the philosophy of complex systems as described by Al-Suwailem (2008).

We consider a set of $n$ funds $F=\left\{f_{i}\right\}_{i=1 \ldots n}$ and a set of $p$ target companies $C=\left\{c_{j}\right\}_{j=1 \ldots p}$.

As mentioned above, funds invest in companies in a two-time process. Let $a_{i, j, t}$ denote the decision of fund $f_{i}$ to invest in company $c_{j}$ at time t. $a_{i, j, t}$ is a binary quantity, which equals 1 in case of positive decision and 0 otherwise.

At each instant $t, s_{j, t}$ denotes the score of the company $c_{j}$, which is a function of its profitability and the investment decisions of "driver funds" (see score calculation). $a_{i, j, t}$ is a function of unique variable $s_{j, t}$. Thus, we can write:

$$
\begin{aligned}
& a_{i, j, t}=f\left(s_{j, t}\right)=f\left(g\left(z_{j, t-1}, a_{d, j, t}\right)\right)= \\
& =h\left(z_{j, t-1}, a_{d, j, t}\right),
\end{aligned}
$$

where $z_{j, t-1}$ represents the independent variable, describing the profitability of the company $c_{j}$ of the period $t-1$, and $a_{d, j, t}$ the vector of investment decisions of "driver funds" in the same company $c_{j}$.

The equation (1) describes the dynamic of a complex system, where agents react based on independent and relative variables (Al-Suwailem, 2008).

On the other hand, let $x_{i, j, t}$ denote the equity ticket to be invested by fund $f_{i}$ in company $c_{j}$ in instant $t$ in case of an auction win. Equity ticket depends on debt availability, target company maximum leverage and the price resulted by the auction run by peer funds. In a conventional market in bubble configuration, debt is assumed to be infinitely available, and leverage can be as high as $95 \%$, so that the equity ticket depends only on the price of the target company reached by the auction.

Let's consider the variables $A v D_{t}, \operatorname{MaxL}_{j}$ and $p_{j}$, which describe, respectively, the available debt in the market at time $t$, the maximum au- thorized leverage for company $c_{j}$ and the auction final price of the company $c_{j}$. Thus, we can write:

$$
\begin{aligned}
& x_{i, j, t}=f\left(A v D_{t}, \operatorname{MaxL}_{j}, p_{j}\right)= \\
& =f\left(p_{j}\right)=h\left(x_{d, j, t}\right),
\end{aligned}
$$

where $x_{d, j, t}$ represents the vector of the prices submitted by the peers in the auction. In particular, in this model, at each round of the auction, $x_{i, j, t}=10 \% \max \left(x_{d, j, t}\right)$, because the fund bids at each round at a price $10 \%$ higher than the current price of the auction.

The equation (2) describes a highly relative system, where exogenous variables are too marginal or non-existent.

As set out by Al-Suwailem (2008), this leads to an unstable or even chaotic system, because "the presence of independent variables [are] an essential mechanism for achieving [the right] balance".

\subsubsection{Implementation}

General context: we examine a universe of the agents, funds $f_{i}$ that invest in companies $c_{i}$ through $\mathrm{LBO}$ acquisition. Each fund $f_{i}$ has an initial commitment $\mathrm{CO}_{i}$ and acquires equity stakes in the companies, financed by equity from his commitment and debt from the bank. Each fund $f_{i}$ selects a set of companies, it will launch a due diligence on, and calculates a score depending on the performance of the company and the behavior of driver funds.

Dynamic of companies: each company $c_{i}$ has an $E_{b i t d a_{i, t}}$, which is dynamic in respect of time at a growth rate equal to EbitdaGrowth ${ }_{i, t}$.

Ebitd $_{i, t}$ has the following dynamic:

Ebitda $_{i . t}=\left(1+\right.$ EbitdaGrowth $\left._{i . t}\right) \cdot$ Ebitda $_{i . t-1}$.

For the below reasons, we propose to model the dynamic of EbitdaGrowth ${ }_{i, t}$ as an auto-regressive process of first order AR (1):

$$
\begin{aligned}
& \text { EbitdaGrowth }_{i, t}= \\
& =\alpha_{0}+\alpha_{1} \cdot \text { EbitdaGrowth }_{i, t-1}+\varepsilon_{i, t} .
\end{aligned}
$$


Equation (4) which describes the dynamic of the EbitdaGrowth refers to an auto-regressive process of first order $\operatorname{AR}(1)$, where $\alpha_{0}, \alpha_{1}$ are constants to determine and $\varepsilon_{i, t}$ are I.I.D $N\left(0, \sigma^{2}\right)$. The reason is that the growth of a company income in a period generally depends on its last period growth thanks to the consistency of the strategy of the managers and the intrinsic performance of the company. In a study of a large sample of micro, small and large firms from the Austrian service industries between 1975 and 2004, Coad and Hölzl (2009) concluded that "large growing firms usually display a positive auto-correlation suggesting that high growth episodes of larger firms stretch over a longer time horizon".

Score calculation: as soon as the fund spots a viable investment (viability is defined as 2-year positive growth of Ebitda), it calculates its score to assess the willingness to enter into an auction process. Score is calculated in the equation (5):

$$
\begin{gathered}
\text { score }_{t} f_{i}\left(c_{j}\right)=\beta_{i} \cdot f\left(n b_{\text {drivers on } c_{j}}, n b_{\text {drivers }}\right)+ \\
+\left(1-\beta_{i}\right) \cdot g\left(\text { Ebitda Growth }_{j, t}, \text { Ebitda Growth }_{j, t-1}\right) \\
f(a, b)=\min \left(4 \cdot \frac{a}{b}, 1\right), \\
g(a, b)=\left\{\begin{array}{cc}
0 & \text { if } \min (a, b)<5 \% \\
10 \cdot \frac{\min (a, 10 \%)+\min (b, 10 \%)}{2} & \text { otherwise }
\end{array}\right.
\end{gathered}
$$

$\beta_{i}$ is the propensity of fund $f_{i}$ to be influenced by "driver" funds $\beta_{i} \in[0,1]$.

$n b_{\text {drivers on } c_{j}}$ refers to the number of "driver" funds willing to participate in the auction of company $c_{j}, n b_{\text {drivers }}$ is the total number of "driver" funds score is a number between 0 and 1 calculated as a weighted average of 2 factors: an endogenous factor, calculated by the function $f$, as proportion of "driver" funds interested by the same investment. The factor is between 0 and 1 and is equal to its maximum when more than $25 \%$ of driver funds are on the same deal. Hence, the factor 4 in the function $f$, and an exogenous factor relative to the company performance, calculated by the function $g$, is also between 0 and 1 . The factor is equal to its maximum when the company has achieved more than $10 \%$ Ebitda growth in the last two periods. Finally, the fund enters in auction for the companies whose scores are beyond a certain threshold.

Auction process: each for-sale-company has either a "primary" status (never backed by a private equity fund), or a "PE backed" status (sold by a private equity fund). When a fund, $f_{i}$ finds a suitable target $c_{j}$, it submits a bid to buy the company at $m \cdot$ Ebitd $_{j} . m$ is either the market multiple (which is an average of the last acquisition multiples) or the ask multiple if the target is sold by another private equity fund. If no competitor is on the deal, the fund acquires the target company at the first attempt, otherwise, it raises the price by $\alpha \%$ before submitting a new bid. At each round of the auction, a fund may leave the auction, according to a certain probability which increases over the rounds, or if the fund has no sufficient commitment to put at least $5 \%$ of equity in the deal, given the last auction bid (Debt is assumed to be infinitely available). The auction ends if one fund remains, and the reached Ebitda multiple exceeds the offer multiple required by the seller.

Investment process: as soon as the auction is complete, the fund and the management acquire the company at a predefined ownership. The maximum equity ticket MaxEquity ${ }_{i}$ invested by the fund $f_{i}$ in the company $c_{j}$ is predefined in its diversification strategy ( $10 \%$ of the fund per deal for example). The debt is calculated as follows:

$$
\begin{aligned}
& \text { Debt }=\min \left(\gamma \% \cdot m \cdot \text { Ebitda }_{j} m \cdot \text { Ebitda }_{j}-\right. \\
& \left.- \text { MaxEquity }_{i}\right),
\end{aligned}
$$

where $\gamma$ is a factor between 0 and 1 , referring to the minimum percentage of the Enterprise value of the company that the fund wishes to fund by debt. Therefore, the leverage can never be less than $\gamma \%$ of the Enterprise value of the fund (for many LBO funds $\gamma$ equals 60\%), because below this level, the operational return is not leveraged enough to meet the expected performance of the fund.

Exit process: the model provides two possible exit routes.

Secondary buyouts: companies backed by the funds are put for sale in the secondary market (i.e. sold to peers), as soon as the holding period is 
equal to 5 years or the market value of the equity (i.e. marketMultiple $\cdot$ Ebit $_{n}$ ) exceeds 3.0x the initial Equity investment, allowing the fund to realize a 3 times money multiple.

In both cases, when a fund decides to exit a company, he asks for a price (or a multiple) so as he could realize 3.0x of his initial investment.

IPO: companies whose equity reaches $10 \mathrm{x}$ the initial investment of the fund are sold to the market exchange through an IPO (Initial Public Offering).

Bankruptcy occurs when either the equity of the company or its aggregate-cash becomes negative.

\subsection{Model flow charts}

The simulation was made using netLogo, a multi-agent programmable modelling environment.

The program consists of four large procedures that run for each tick of the simulation: the main procedure, the bidding procedure, the auction procedure and the aging procedure.

\subsubsection{Main function}

The main procedure is launched at first. It initializes the environment of companies and funds, and computes the companies' performances, based on their Ebitda simulation and financial expenses, then checks if any company fails to meet its obligations and should go bankrupt.

\subsubsection{Bidding procedure}

The bidding procedure deals with the companies that are not held by private equity funds. These companies are still in the market and have never been backed by a fund.

At each tick, each fund scores a set of random spotted companies and decides either to submit a bid or not. The decision depends not only on the score calculation described above, but also on its remained commitment and concentration ratios. If the fund decides to bid on a company, the auction procedure is called.

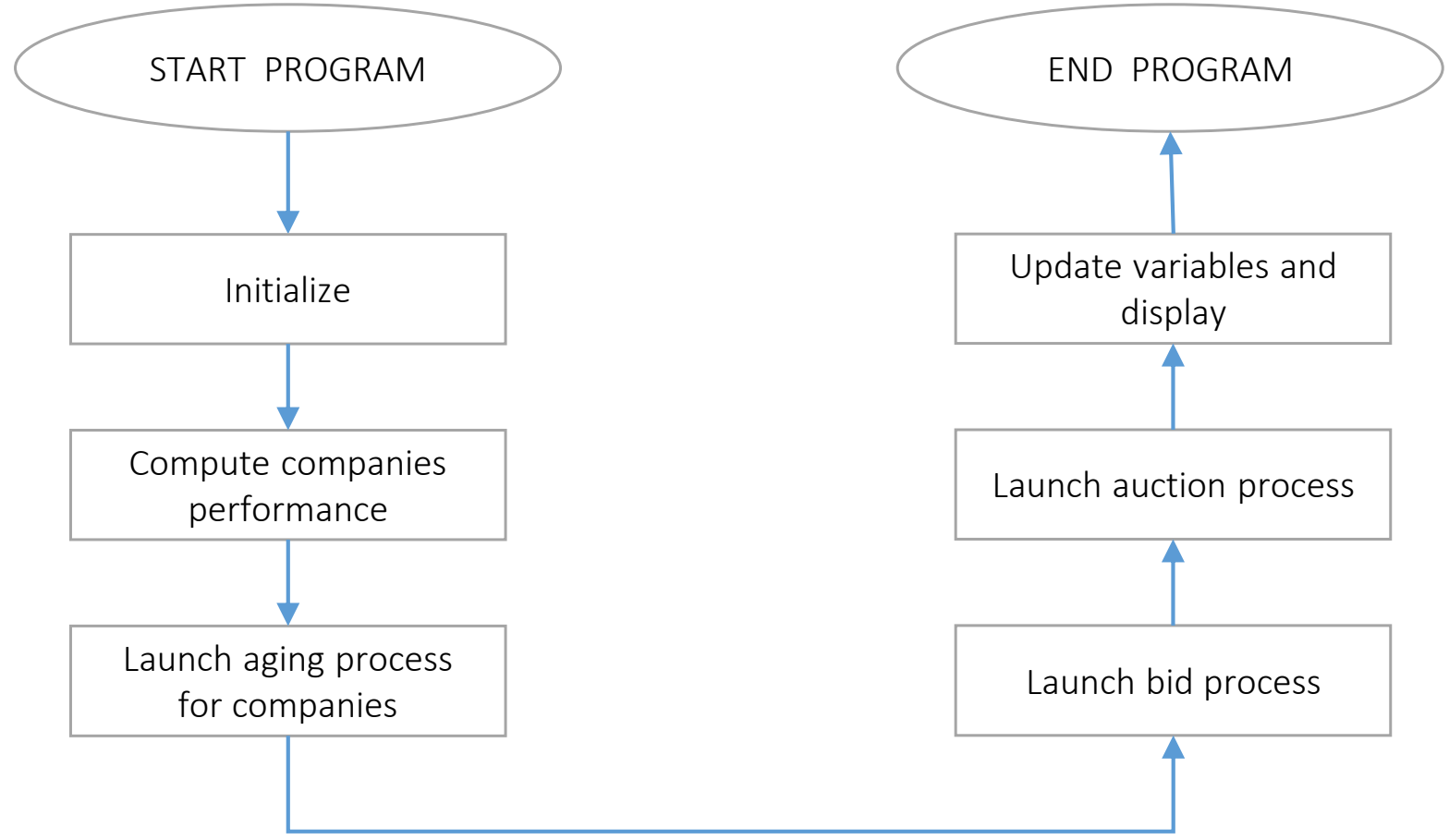

Figure 4. Flow chart of the main program 'Go' 
Source: Prepared by the authors.

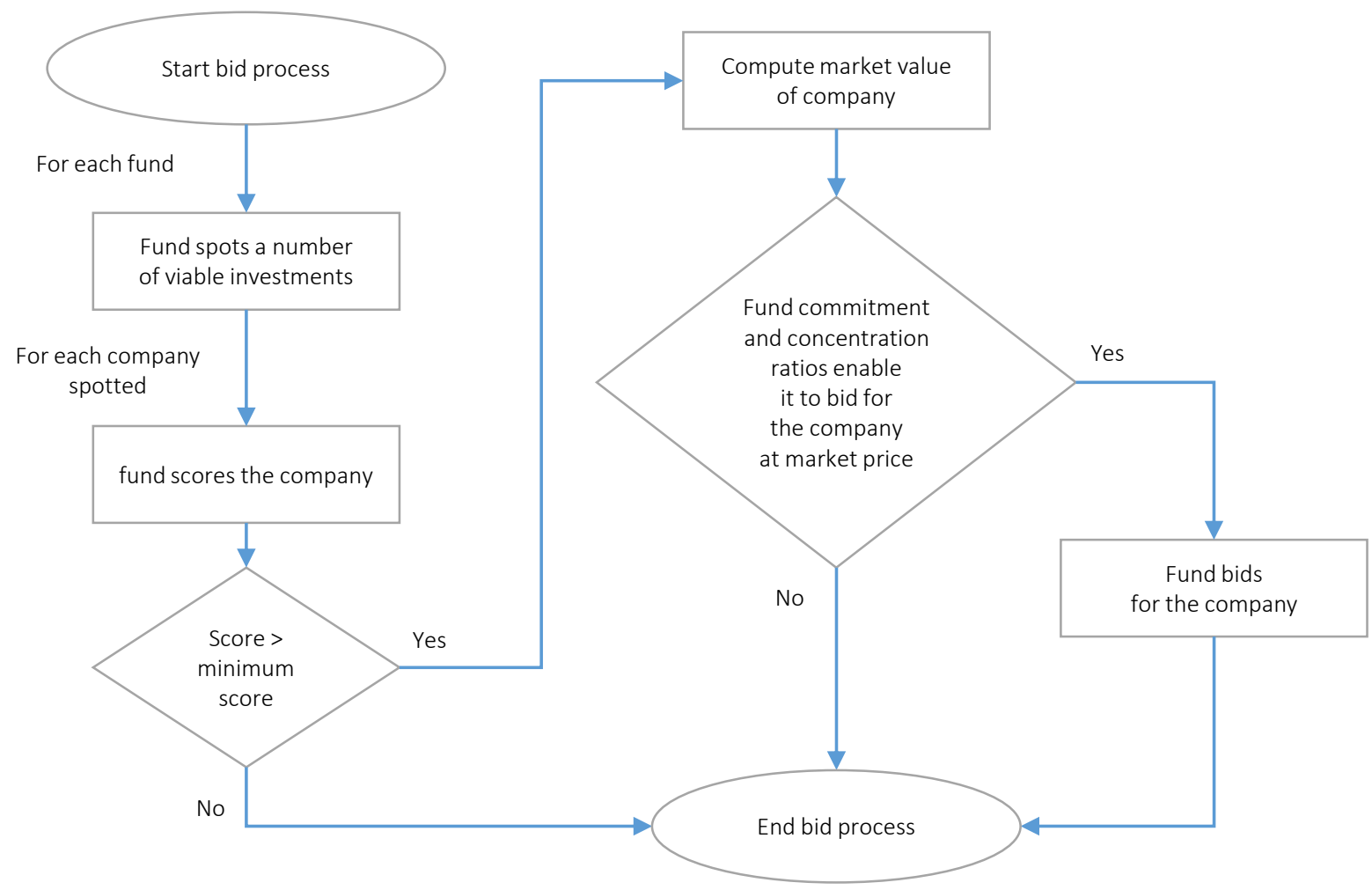

Figure 5. Flow chart of the bidding function

\subsubsection{Auction procedure}

The auction procedure deals with the companies that are not held by private equity funds, which have received a bid from a least one fund. If only one fund submits its bid to a company, there is no auction process and the funds acquires the company by mutual agreement.

If several funds submit their bids to a single company, an auction process is launched.

At each tick, each funds submits a higher bid than the last one. The program spots the funds that should quit the competition either because they judge the deal too expensive (according to a probability to quit) or because they cannot pursue the auction for lack of sufficient funds.

The auction ends when one fund remains.

\subsubsection{Aging procedure}

The aging procedure deals with the companies that are held by private equity funds. These companies are either "for sale" or not, i.e. "PE backed".

The procedure first changes the status of "PE backed" companies to "for sale" when they are held for more than 5 years or when their book value exceeds 3 times the initial acquisition price. Book Value is calculated as follows:

Book value $=$ Multiple offer $x$ Ebitda - Debt.

Companies that are for sale for more than 1 year see their multiple offer reduced by a multiplying factor. At each tick, if a "for sale" company's book value exceeds 5 times the initial investment, it goes public through an IPO.

At each tick, the procedure checks whether a company does not meet its financial obligations, in which case it goes bankrupt. 


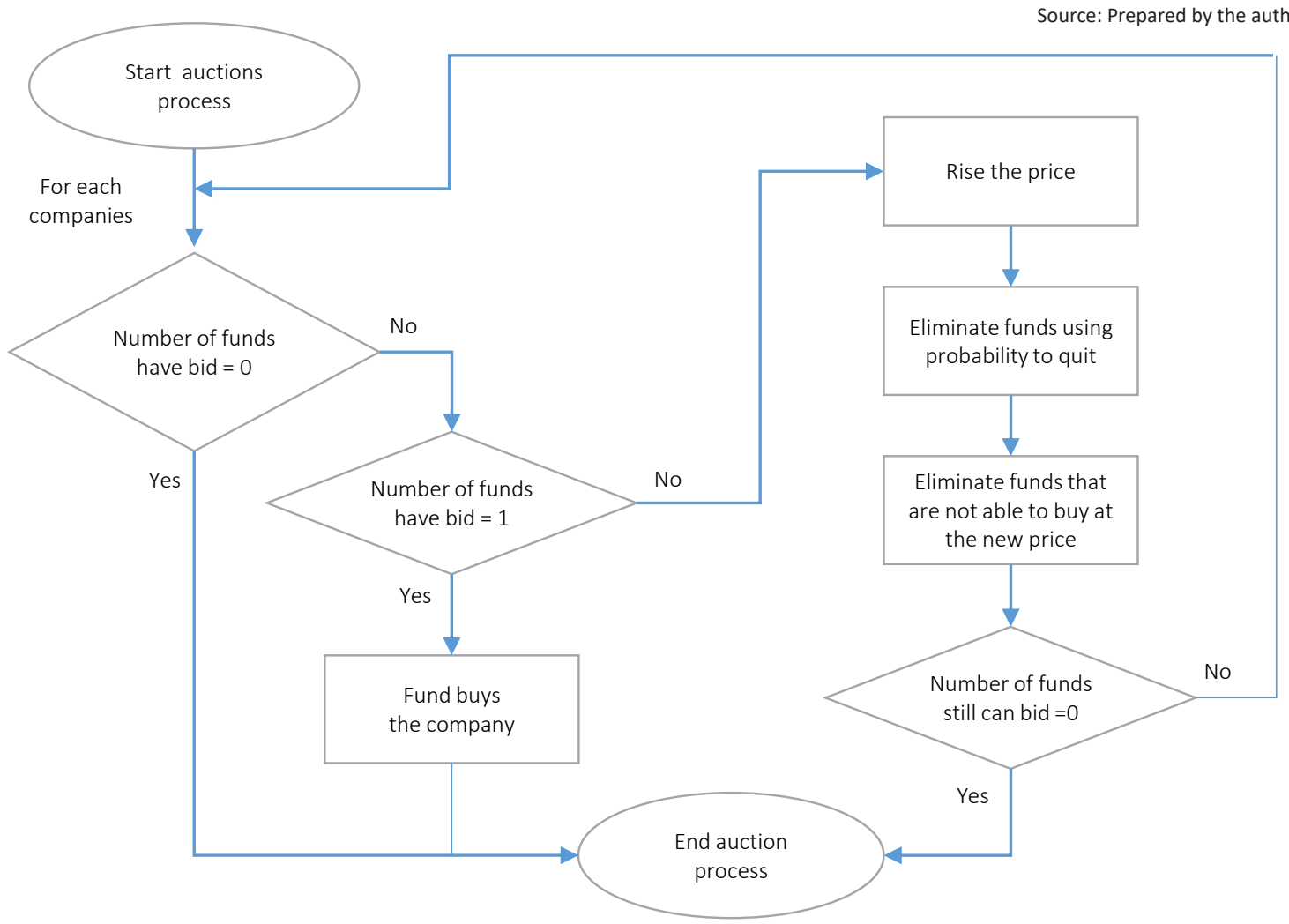

Figure 6. Flow chart of the auction function

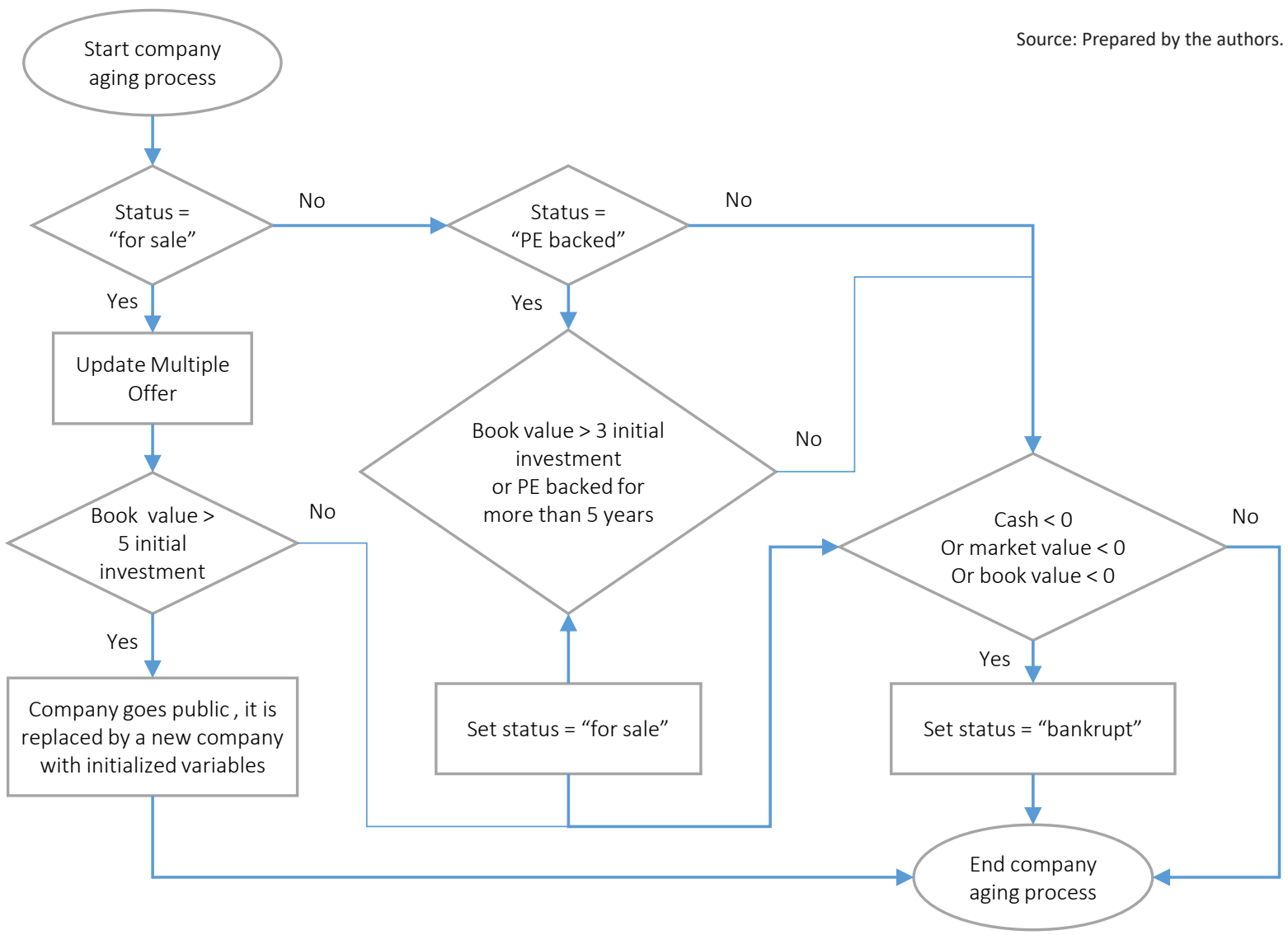

Figure 7. Flow chart of the aging function 


\section{RESULTS AND DISCUSSION}

\subsection{Conventional market case}

\subsubsection{Assumptions}

In the conventional case, the model simulation is run with the following assumptions.

Table 1. Model assumptions [conventional market case]

\begin{tabular}{l|c}
\hline \multicolumn{1}{c}{ Parameter } & Value \\
\hline Type of market & Conventional \\
\hline $\mathrm{Nb}$ of periods & 40 years \\
\hline $\mathrm{Nb}$ of funds & 25 \\
\hline $\mathrm{Nb}$ of companies & 500 \\
\hline $\mathrm{Nb}$ of driver funds & 5 \\
\hline Min leverage at acquisition & $60 \%$ \\
\hline Max leverage at acquisition & $95 \%$ \\
\hline
\end{tabular}

\subsubsection{Results and discussion}

These charts represent the behaviour of some economic indicators in a period of a Market boom.

In fact, Figure 8 represents the evolution of average Ebitda multiple in a time-lapse of 40 periods. The fact that it shows a steady growth, means that the market becomes more expensive as time passes by. This behavior is not surprising, because we assumed the debt to be infinitely available, and the buyers show fierce competition to win the deals in the auction, without worrying about the burden of the high leverage. In our model, we assumed that the bidders submit a higher bid as long as they can afford to pay the price by supplementing by the available debt, and that the maximum authorized leverage is not reached. In the real life, however, debt cannot be assumed to be infinite. Banks and hedge funds show some reluctance or require personal warranties when it comes to highly inflated prices. This limitation of the model might cause excessive prices, but the trend and the global behavior are coherent.

This is also clear in Figure 9, which represents the level of debt in respect to the Enterprise value in the underlying companies. The level of leverage is higher than average, and the companies do not reimburse their debts even after long period of time. This is easily understood, because the operational result of the underlying companies barely pays their interest and do not leave any reminder to pay off the principal. In general, except for some very profitable companies, when the debt burden is too high, this causes the recourse to other bank debt or the rescheduling of the existent debt with high costs and heavier covenants. In these conditions, the weak companies go bankrupt very quickly, failing to face the financial challenge, even if their operational performance is decent. Figure 12 shows how more than $10 \%$ of the companies collapsed after 40 periods.

Figure 10 represents the evolution of companies' equity level after 40 periods. Even though the chart is showing a good progress, the implied period growth rate is about $3 \%$, which is a poor profit

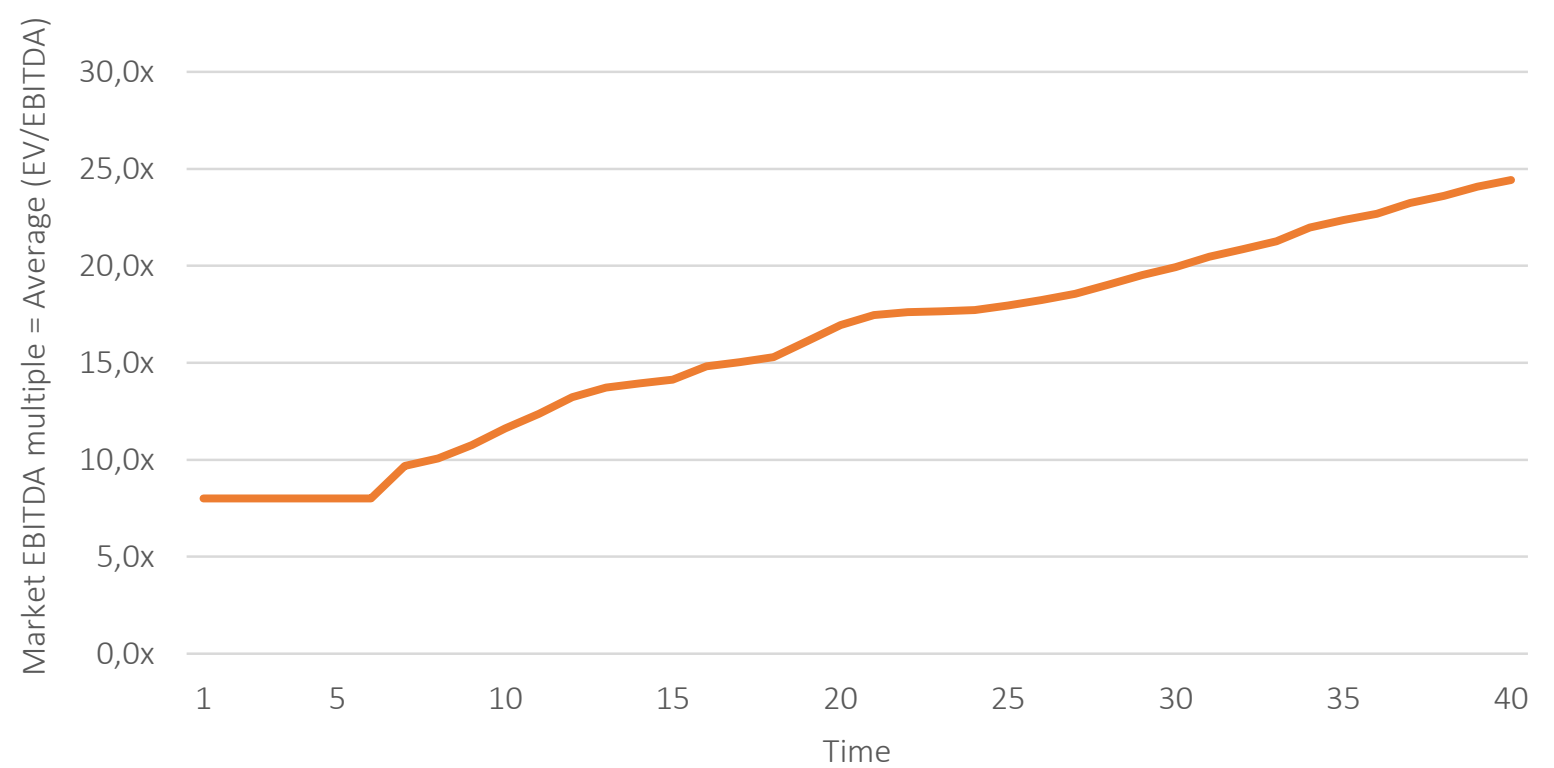

Figure 8. Market ebitda multiple evolution in a conventional LBO market 


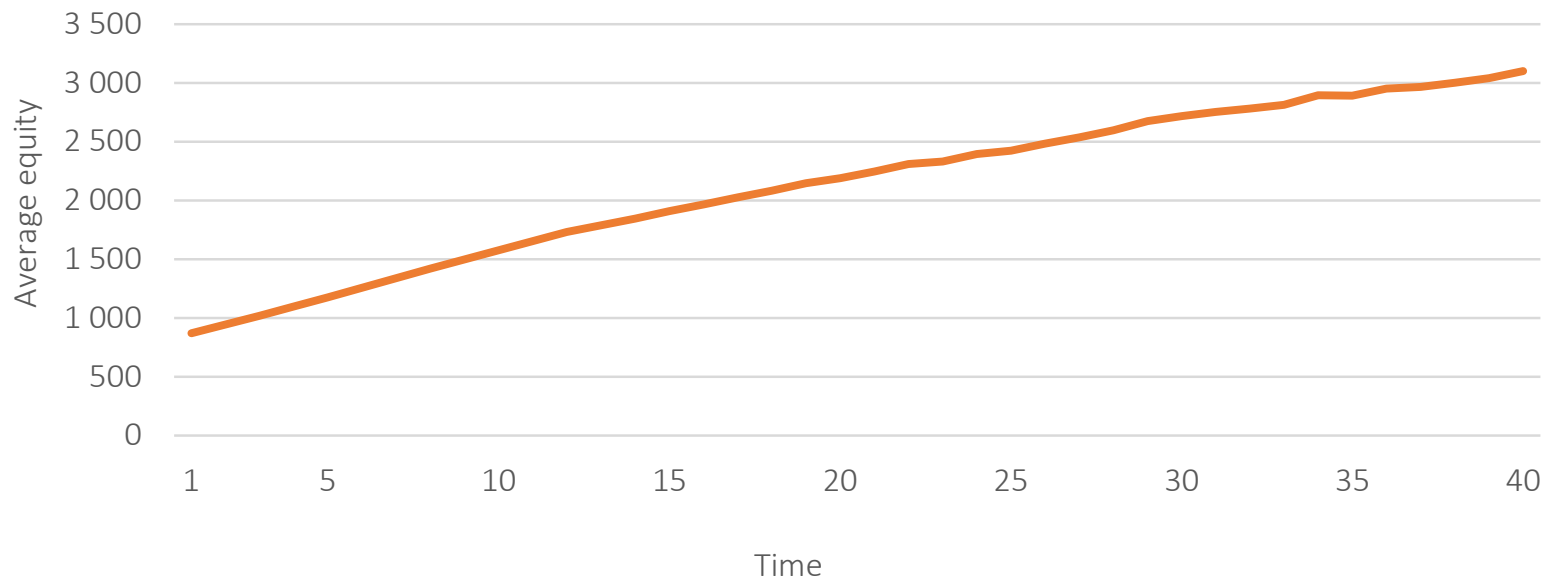

Figure 9. Evolution of Leverage ratio (Debt/Enterprise value) in conventional LBO market

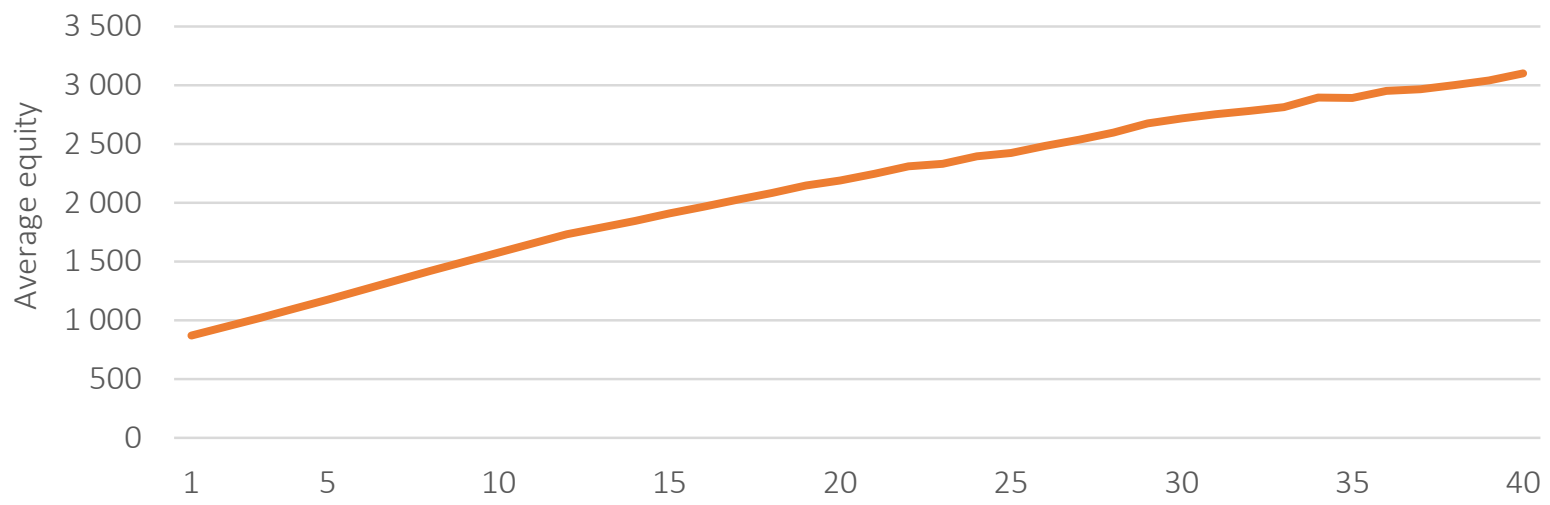

Time

Figure 10. Evolution of average companies' equity in a conventional LBO market

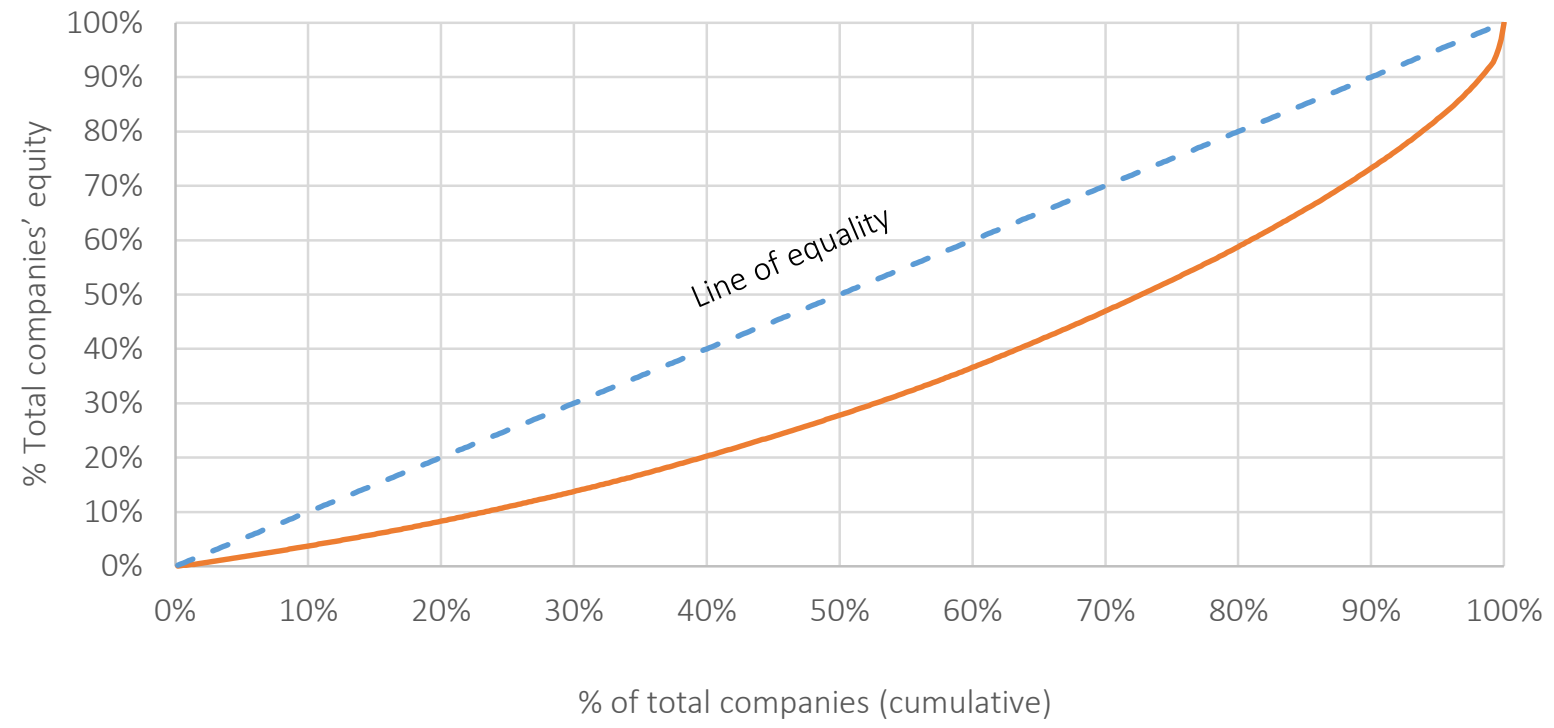

Figure 11. Lorentz curve of companies' equity after 40 periods in a conventional LBO market 


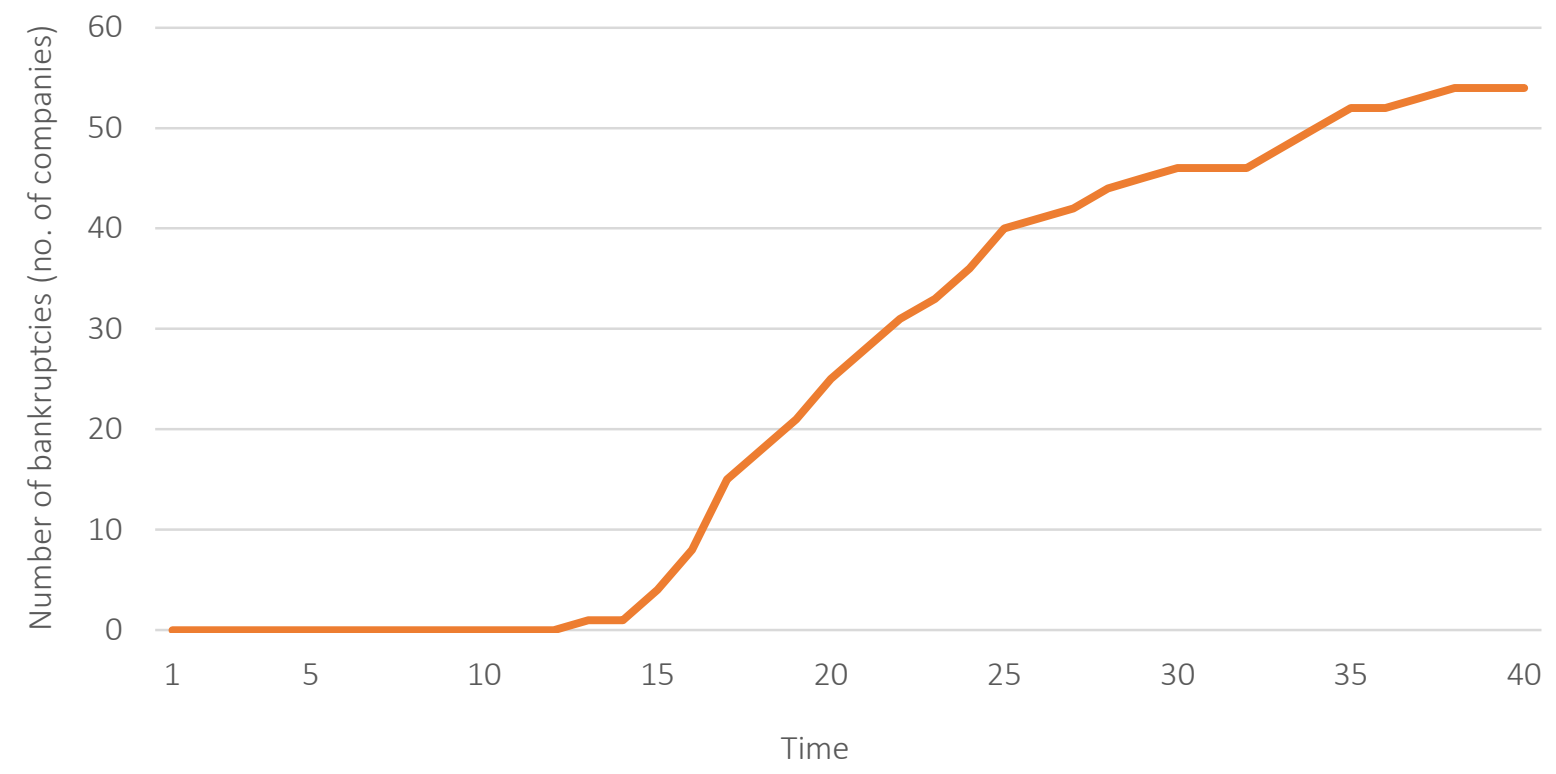

Figure 12. Evolution of the number of bankruptcies in a conventional LBO market (out of 500 companies)

in respect to the borne risk. Again, this a direct consequence of the high level of the financial cost of the bank debt.

Finally, another interesting result of these simulation is the dispersion of wealth between the funds. Figure 11 exhibits the Lorentz curve of equity at the last year of simulation. The chart shows a weak dispersion of wealth between funds, with a Gini index of 0.33 . As calculation does not include bankruptcies, this means that funds that struggle to survive get an adequate share of the pie.

\subsection{Sharia compliant market case}

\subsubsection{Assumptions}

In the Sharia compliant case, the model simulation is run with the following assumptions.

Table 2. Model assumptions [Islamic market case]

\begin{tabular}{l|c}
\hline \multicolumn{1}{c|}{ Parameter } & Value \\
\hline Type of market & Sharia compliant \\
\hdashline $\mathrm{Nb}$ of periods & 40 years \\
\hline $\mathrm{Nb}$ of funds & 25 \\
\hline $\mathrm{Nb}$ of companies & 500 \\
\hline $\mathrm{Nb}$ of driver funds & 2 \\
\hline Min leverage at acquisition & $0 \%$ \\
\hline Max leverage at acquisition & $33 \%$ \\
\hline
\end{tabular}

In this case, while the general assumptions are kept the same as the previous one, some of the assumptions have been modified to reflect the legal constraints in the Islamic Law, such as the maximum leverage, which is amended to $33 \%$, as stipulates the Sharia Law.

\subsubsection{Results and discussion}

These charts represent the behavior of some economic indicators in similar condition of the conventional market, but with the restrictions described above.

Figure 14 represents the evolution of average Ebitda multiple in a time-lapse of 40 periods. Unlike the conventional market, it shows a smooth increase in Ebitda multiple that remains stable after reaching a market equilibrium. This means that the market does not go into a bubble and prices tend to stabilize. This is easily understood by the fact that the debt is not highly available and restricted to $33 \%$ of the Enterprise value, so the auctions do not go through too many rounds, raising the price significantly. This is also visible in the Figure 13, which shows a "bell curve", with a maximum leverage around $12 \%$. Unlike the conventional market, companies succeed to reimburse their debts so that the leverage decreases significantly after a few periods. This means that the companies can 


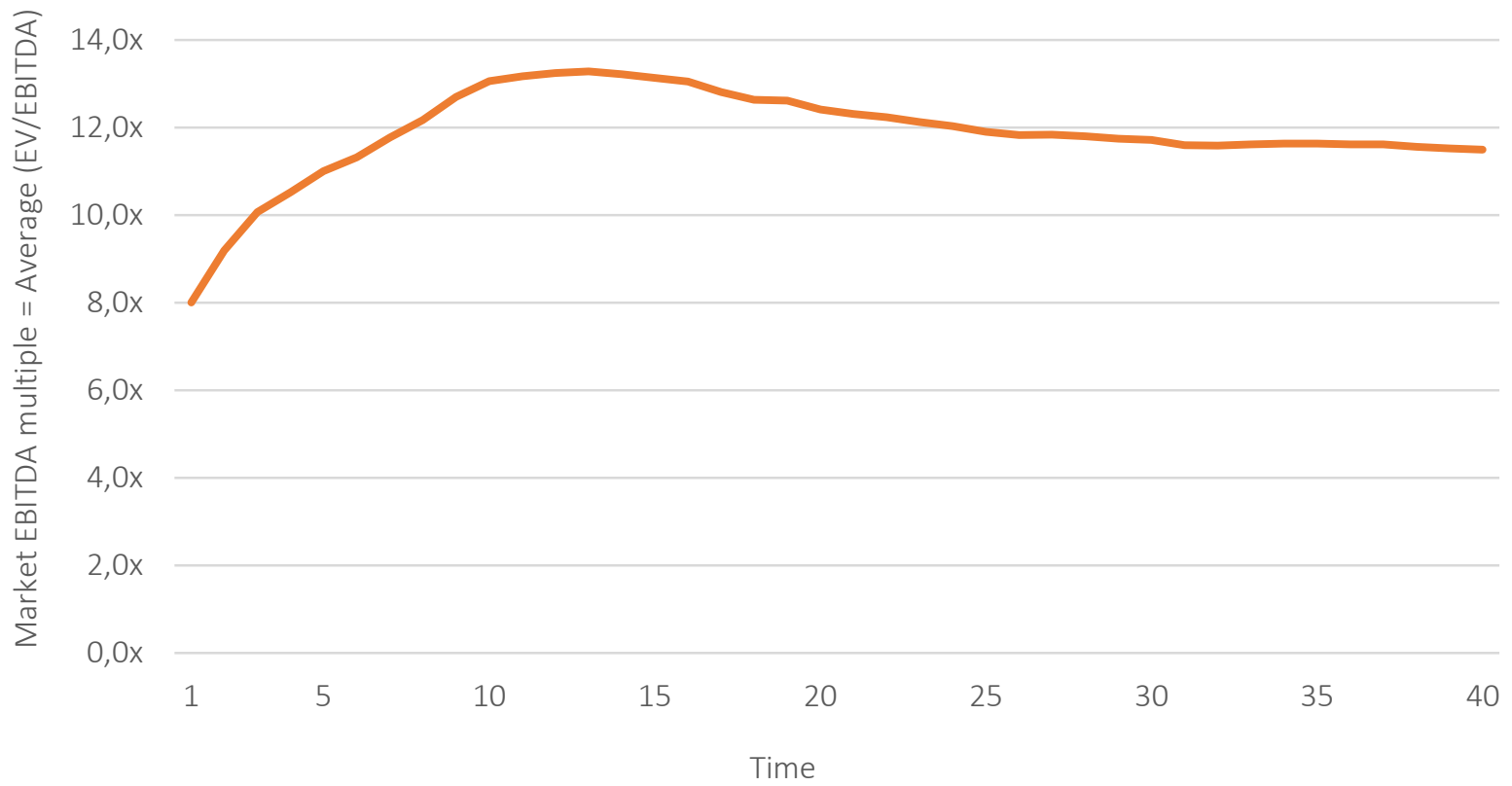

Figure 13. Market Ebitda multiple evolution in an Islamic LBO market

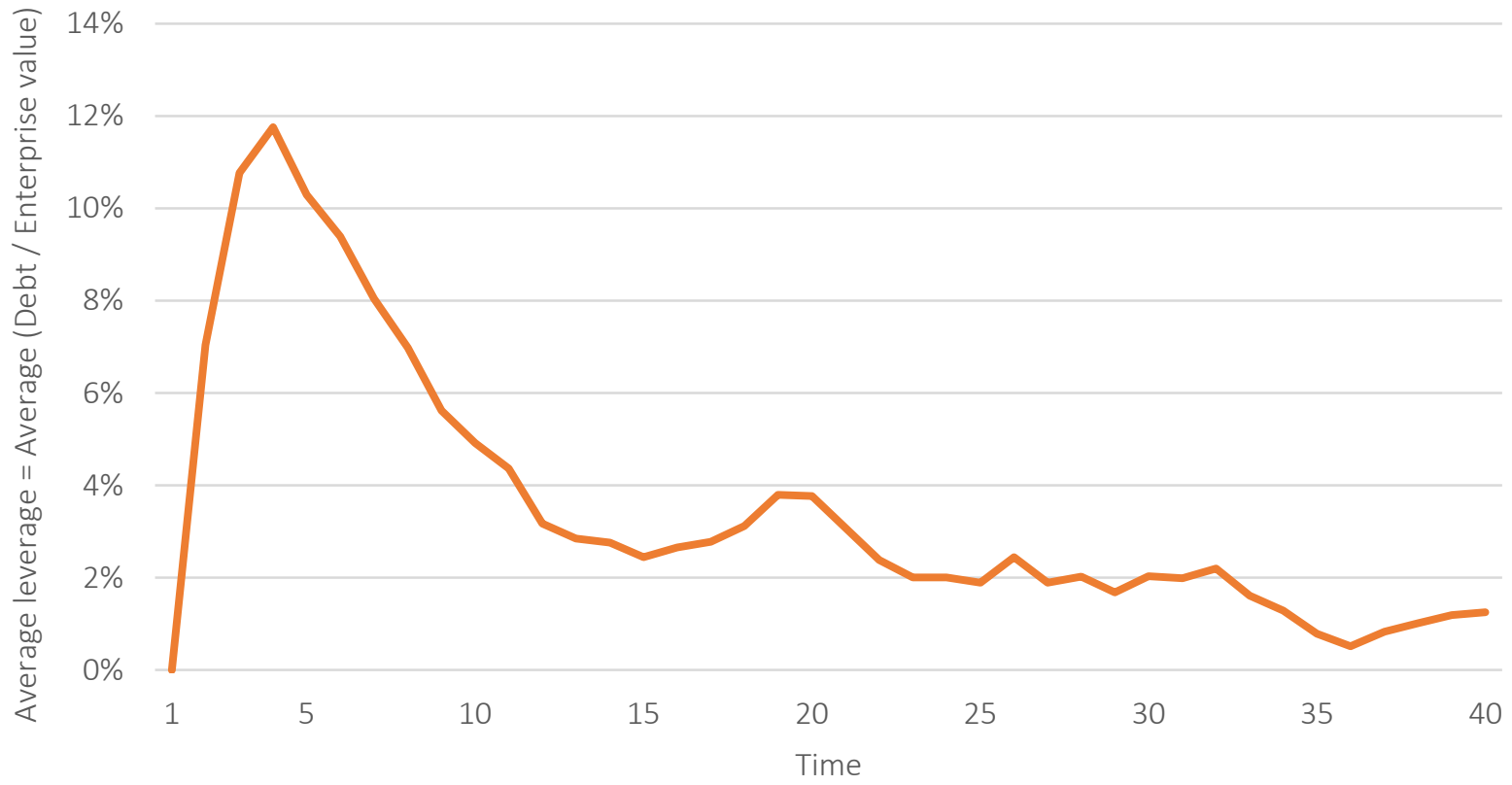

Figure 14. Evolution of Leverage ratio (Debt/Enterprise value) in Islamic LBO market

easily bear the burden of low debt and meet their number of bankruptcies shown in Figure 17. annual instalments.

For the same reasons as above, even weak companies with relatively low operational performance do not go bankrupt quickly, because the financial expenses are not very high. This explains the low
On the other hand, in terms of performance, the average equity level of companies grows at a rate of $4.5 \%$ per annum as stated in Figure 16, due to the low financial expenses and the subsistence of weak companies while crossing financial turbulences. 


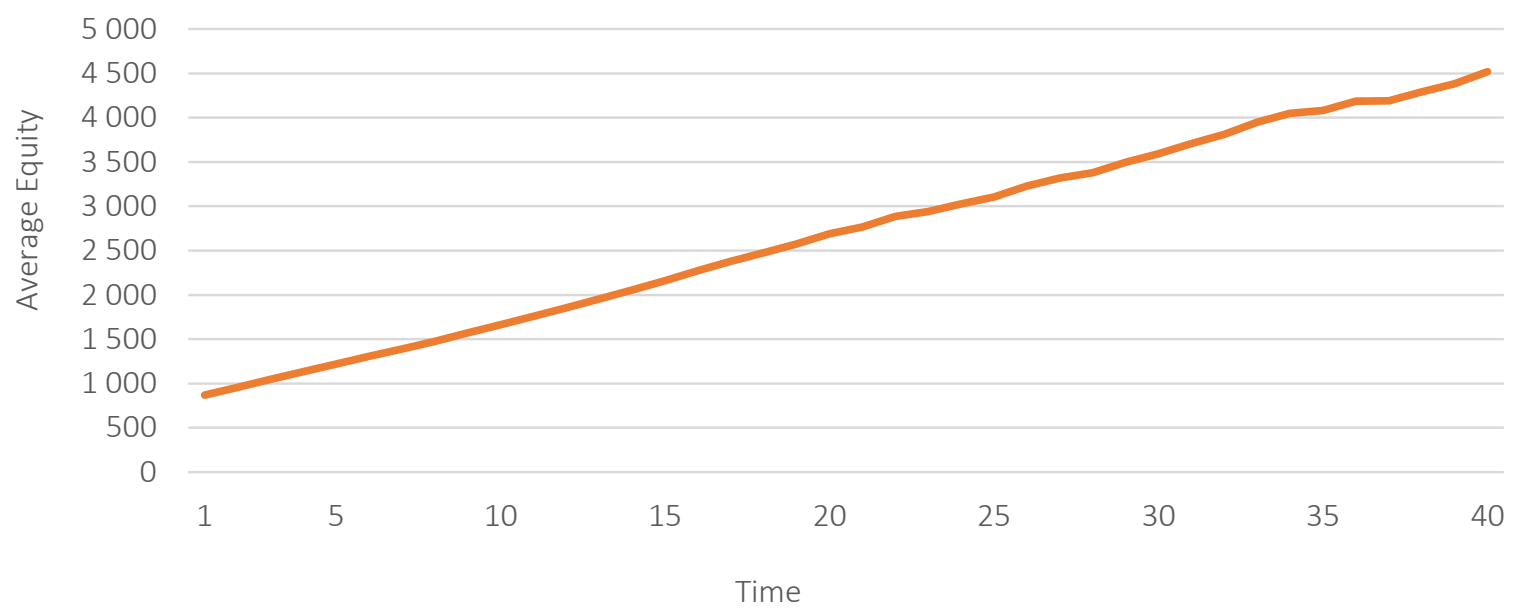

Figure 15. Evolution of average companies' equity in Islamic LBO market

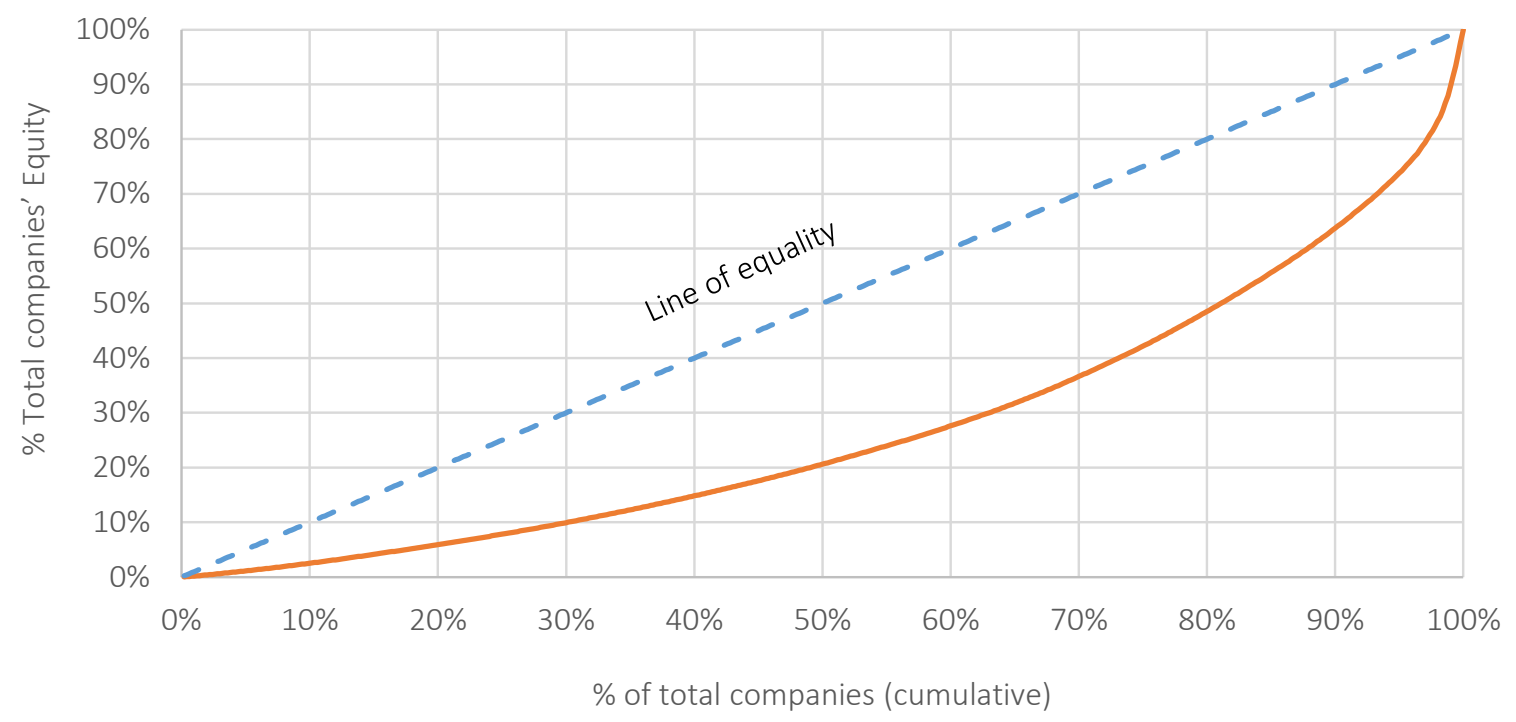

Figure 16. Lorentz curve of companies' equity after 40 periods in Islamic LBO market

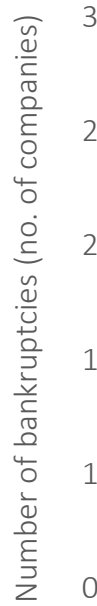

2

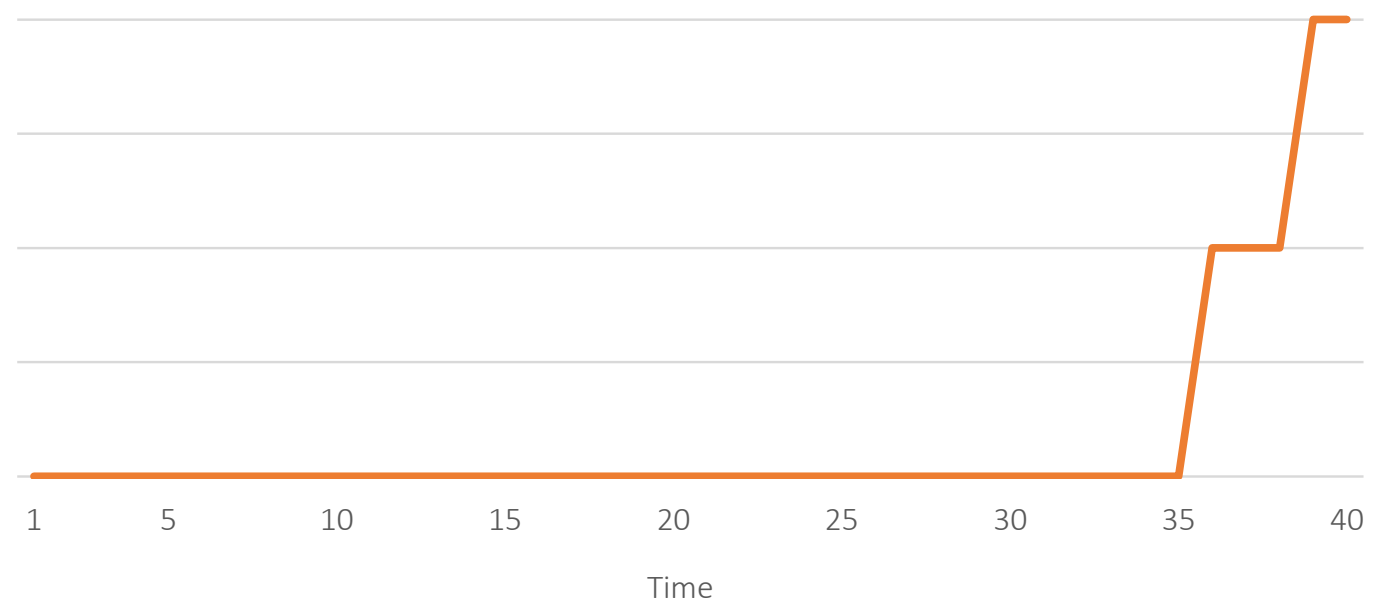

Figure 17. Evolution of the number of bankruptcies in Islamic LBO market (out of 500 companies) 
Finally, and counterintuitively, the wealth distribution displays more dispersed wealth in comparison to conventional market, with a Gini index of 0.45. Companies in a Sharia compli- ant market might survive with weak operational return, because the financial fees are low or non-existent, this explains the higher dispersion of equity value.

\section{CONCLUSION}

The overuse of debt was being spotlighted by many economists in the last century, as one of the main factors that cause economic booms and busts. However, new disasters are yet to be experienced by the financial markets, period after period, without drawing out lessons learned from past mistakes. "It is quite amazing that there is no collective memory that goes beyond five years, or that the world is organized in such a way that history keeps on repeating", says Ludovic Phalippou, a finance professor at the University of Oxford's Saïd Business School. The 2009 mortgage sub-prime crisis is nothing but a powerful example of how again, the misuse of debt has led to a housing bubble in the United States.

The LBO industry was particularly affected by the misuse and overuse of leverage in the recent past years and this has caused many profitable business to collapse under the burden of too much debt.

In this paper, we have tried to illustrate how a simple auction-driven LBO market, fuelled with too much debt and influenced by some driver actors can lead to chaos and financial disasters. Meanwhile, a Sharia compliant market, with simple "safeguards" against the overuse of "debt" and the under-assessment of risks (covenant-lite, ...), leads to a healthy environment with more added value and less bankruptcies. In this model, we tried to exhibit a few number of factors, which can cause conventional LBO markets to trigger a boom dynamic, and how Islamic finance helps mitigate some of them. The simulation gives unequivocal results with regard to the stability of Islamic LBO environments and to the resilience of companies within a such configuration. In fact, as shown by the simulation results above, the simple limitation of maximum leverage to $33 \%$ in the underlying companies, has resulted in less expensive market at roughly half the prices of the conventional market (25x vs. $13 \mathrm{x}$ Ebitda), less bankruptcies (50 vs. 3) and higher growth of companies' equity ( $4.5 \%$ p.a. vs. $3.0 \%$ p.a.). This is not to mention the effect of limited imitation in reducing the volatility of the market.

However, it is to bear in mind that the model used in this paper comes with some limitations that should be considered. In fact, even in the times of very abundant liquidity, debt is not indefinitely available. Banks and hedge funds are sometimes reluctant to enter very high leveraged deals with no proven economic added value or require personal guarantees, so that the managers do not speculate and participate in the artificial inflation of prices. In addition, when two or three funds remain in a very competitive auction, they might consider co-investing in the same deal, so that prices stay at a reasonable level, even if this means reducing their ticket sizes. These non-exhaustive limitations moderate the idea of prices heading to infinity in this market configuration.

Another limitation which might be subject to future research is the debt renegotiation. A company that faces issues to redeem its debt should not go systematically bankrupt, but can have recourse to additional debt or rescheduling of its annuities. Although this generally comes with stricter conditions and higher fees, it could help the company overcome a period of cash-flow issue and recover stronger. However, the drawback is that the debt negotiation could maintain the company in a state of artificial viability when it is irrevocably required to go out of business. This may create a dangerous Ponzi scheme, where more debts serve to redeem anterior debts, with terms and conditions that are often less favorable for the target company.

This seems to be an interesting orientation for further research and benchmark with the Islamic LBO market, which does not allow this practice. 


\section{REFERENCES}

1. Acharya, V. V, Franks, J., \& Servaes, H. (2007). Private equity: Boom and bust? Journal of Applied Corporate Finance, 19(4), 44-53. https://doi.org/10.1111/j.17456622.2007.00158.x

2. Ahmed, A. (2010). Global financial crisis: an Islamic finance perspective. International Journal of Islamic and Middle Eastern Finance and Management, 3(4), 306-320. https://doi. org/10.1108/17538391011093252

3. Alam, N. (2010). Resilience of Islamic finance during credit crunchEmpirical evidence from European market (8th International Conference on Islamic Economics and Finance). Retrieved from https:// www.academia.edu/1396893/Resilience_of_Islamic_Finance_During_Credit_Crunch_Empirical_Evidence_from_European_Market

4. Al-Suwailem, Sami Ibrahim (2008). Islamic Economics in a Complex World: Explorations in Agent based Simulation (Research Paper). The Islamic Research and Teaching Institute (IRTI). Retrieved from https://ideas.repec. org/p/ris/irtiop/0238.html

5. Ang, J., Hutton, I., \& Majadillas, M. A. (2014). Manager divestment in leveraged buyouts. European Financial Management, 20(3), 462493. https://doi.org/10.1111/j.1468036X.2013.12018.X

6. Bain \& Company (2017). Global private equity report 2017. Retrieved from https://psik.org.pl/ images/publikacje-i-raporty---publikacje/BAIN_REPORT_Global_ Private_Equity_Report_2017.pdf

7. Biancone, P., \& Radwan, M. (2016) European companies: evaluation for sharia compliance "opportunities and challenges". European Journal of Islamic Finance, 5, 1-8. http://dx.doi.org/10.13135/24212172/1803

8. Chu, F. J. (1990). The High-Yield Debt Market: Trash or Treasure? Journal of Business Strategy, 11(4), 42-47. https://doi.org/10.1108/ eb060074
9. Coad, A., \& Hölzl, W. (2009). On the autocorrelation of growth rates. Journal of Industry, Competition and Trade, 9(2), 139-166. Retrieved from https://link.springer.com/ article/10.1007/s10842-009-0048-3

10. Cochrane, J. H. (2005). The risk and return of venture capital. Journal of financial economics, 75(1), 3-52. https://doi.org/10.1016/j. jfineco.2004.03.006

11. Farid, F. M. A. (2012). Shariah compliant private equity and Islamic venture capital. 22 George Square, Edinburgh EH8 9LF: Edinbugh University Press. Retrieved from https://books.google.co.ma/ books?hl=fr\&lr=\&id=1Z1vAAA AQBAJ\&oi=fnd\&pg $=$ PP $1 \& d q=F$ arid,+Fara + Madehah + Ahmad +( 2012).+Shari\%E2\%80\%99ah+co mpliant+private+equity+and+Isla mic+venture+capital.+22+George +Square,+Edinburgh+EH8+9LF: + Edinbugh+University+Press\&o ts=h4Yw4oniFf\&sig=ZA9S1Qv1 3p5-33XT0qDhOWzkdnM\&red ir_esc $=\mathrm{y} \# \mathrm{v}=$ onepage\&q\&f=false

12. Fraser-Sampson, G. (2011). Private equity as an asset class. John Wiley \& Sons.

13. Hurduzeu, G., \& Popescu, M.-F. (2015). The History of Junk Bonds and Leveraged Buyouts. Procedia Economics and Finance, 32, 12681275. https://doi.org/10.1016/ S2212-5671(15)01504-X

14. Kaplan, S. N., \& Stromberg, P. (2009). Leveraged buyouts and private equity. Journal of Economic Perspectives, 23(1), 121-146. Retrieved from https://www. aeaweb.org/articles?id=10.1257/ jep.23.1.121

15. Lowenstein, L. (1985). Management buyouts. Columbia Law Review, 85(4), 730-784. Retrieved from https://heinonline.org/HOL/ LandingPage?handle=hein.journals $/$ clr85\&div $=37 \&$ id $=$ \&page $=$

16. Lustenberger, M. (2007). Risk Aspects in Private Equity Investments. Retrieved from https://papers.ssrn. com/sol3/papers.cfm?abstract_ $\mathrm{id}=1022280$
17. Meyer, T. (2014). Private equity unchained: Strategy insights for the institutional investor. Springer. Retrieved from https://books.google fr/books?hl=fr\&lr=\&id=0RVvBA AAQBAJ\&oi=fnd\&pg $=$ PP1\&dq $=$ Meyer,+Thomas+(2014).+Private+ equity+unchained:+Strategy+insi ghts+for+the+institutional+invest or. + Springer\&ots $=$ sL4Y2 $w R X U U$ \&sig=fCtUfXcVae3dj4ZsmRhoIfI4 $\mathrm{fi} 4 \# \mathrm{v}=$ onepage $\& \mathrm{q} \& \mathrm{f}=$ false

18. Olayemi, A. A. M., Hasan, A., Ibrahim, U., \& Mahamood, S. M. (2015). Modus Operandi of the Islamic Money Market: A Proposal for Holistic Shariah Adaptation. Journal for Humanities and Social Sciences, 13, 42-67. Retrieved from https://www.researchgate.net/ publication/319192547_Special_ Issue_on_Islamic_Finance_Modus_Operandi_of_the_Islamic_ Money_Market_A_Proposal_for_ Holistic_Shariah_Adaptation

19. Phalippou, L., \& Gottschalg, O. (2008). The performance of private equity funds. The Review of Financial Studies, 22(4), 1747-1776. Retrieved from https://www.jstor.org/ stable $/ 30225708$ ? seq=1\#page scan tab contents

20. Preqin (2017). 2017 Preqin Global Private Equity Venture Capital Report. Retrieved from http://docs. preqin.com/samples/2017-PreqinGlobal-Private_Equity-and-Venture-Capital-Report-Sample-Pages. pdf

21. Vernimmen, P., \& Quiry, P. (2014). Corporate finance: theory and practice. John Wiley \& Sons. Retrieved from https://www.goodreads.com/ book/show/3365494-corporatefinance

22. Wouters, P. (2008). Islamic Private Equity Funds. Islamic Finance News, 17, 1-16. 